Ritrýnd grein birt 6. nóvember 2019

\title{
Samband menntunar foreldra við frammistöðu pátttakenda í PISA-könnuninni á Norðurlöndum
}

\author{
Berglind Gísladóttir, Hans Haraldsson og Amalía Björnsdóttir
}

Abstract $>$ Um höfundana $\backslash$ About the authors $\rightarrow$ Heimildir

Tilgangur rannsóknarinnar var að skoða tengsl milli menntunar foreldra og árangurs barna peirra í PISA (e. Programme for International Student Assessment). Alveg frá pví að PISA var lagt fyrir í fyrsta sinn hefur pví verið haldið fram að Ísland hafi pá sérstöðu að hverfandi tengsl séu milli menntunar foreldra og árangurs barna peirra í PISA, ólíkt pví sem gerist í öđrum löndum. Í pessari rannsókn voru notuð gögn úr PISA frá fyrirlögn árið 2015 og einskorðaðist greiningin við Norðurlöndin fimm. Markmiðið var að svara spurningunni hvort Ísland hefði raunverulega sérstöðu í pessum efnum eða hvort lítil tengsl sem hefðu komið fram til pessa mætti rekja til peirra aðferða sem notaðar voru til að meta tengsl menntunar foreldra og árangurs barna peirra. Niðurstöður pessarar rannsóknar benda til pess að á öllum Norðurlöndum sé umtalsverður munur á meðalárangri pátttakenda sem eiga foreldra með grunnskólamenntun og peirra pátttakenda sem eiga foreldra með háskólamenntun. Pá sýna niðurstöður skýrt að Ísland er ekki verulega frábrugðið hinum Norðurlöndunum að pessu leyti. Ef viðmið OECD um meðalframfarir nemenda á einu skólaári eru notuð til túlkunar er ekki hægt að álykta annað en að munur á meðalárangri barna grunn- og háskólamenntaðra foreldra sé mjög verulegur. Niðurstöđur sýndu að pessi munur samsvarar meðalframförum á tveimur skólaárum í stærðfræðilæsi, meðalframförum á rúmum tveimur skólaárum í lesskilningi og tæpum tveimur árum í náttúrufræðilæsi.

Efnisord: PISA, menntun foreldra, námsárangur, félagsleg staða, alpjóðlegur samanburður

\section{Inngangur}

Fræðimenn hafa lengið haldið pví fram að námsárangur barna og ungmenna mótist af mörgum ólíkum páttum, bæði innan og utan skóla, og peir hafi áhrif á hvernig börnum tekst að fóta sig í námi. Samfélagið sem einstaklingar búa í mótar pá en ekki síður nærsamfélagið, pað er fjölskyldan, vinir, jafningjahópur, tómstundir og áhugamál. Samspil pessara félagslegu pátta, auk skólastarfs, er talið vera mótandi afl í námsgengi barna og ungmenna (Bong, 2008; Coleman o.fl., 1966; Israel, Beaulieu, og Hartless, 2001; Morgan og Sørensen, 1999; Sun, 1999).

Dví hefur oft verið haldið á lofti pegar fjallað er um niðurstöður alpjóðlegra kannana, eins og til að mynda PISA (e. Program for International Student Assessment), að einn af styrkleikum íslensks menntakerfis sé mikill jöfnuður. Pannig sé munur á árangri milli skóla á Íslandi sá minnsti sem finnist í pátttökuríkjunum og hið sama eigi við um pjóðfélagsstöðu, hún skipti hér minna máli 
en í nokkru öðru pátttökulandi (Menntamálastofnun, 2017). Í skýrslu um niðurstöður PISA 2009 var pó bent á að pessi munur hefði aukist miðað við fyrri niðurstöður úr PISA (Almar M. Halldórsson, Ragnar F. Ólafsson, Óskar H. Níelsson og Júlíus K. Björnsson, 2010) en ítrekað að enn væri hann engu að síður mjög lítill.

Mikill jöfnuður í skólakerfinu er vissulega nokkuð sem gleðjast má yfir en rétt er bó að athuga í pessu sambandi að á Íslandi er félags- og efnahagsleg staða skóla og heimila einhver sú besta sem pekkist á meðal PISA-pjóða, eins Almar M. Halldórsson, Ragnar F. Ólafsson og Júlíus K. Björnsson (2013) hafa bent á. Almar og félagar (2013) tala einnig um mikinn jöfnuð í tækifærum „nánast óháð pjóðfélagsstöðu foreldra“ (bls. 64) og segja að tengsl milli pjóðfélagsstöðu og læsis sé helst að finna í skólum á höfuðborgarsvæðinu, en pau séu mjög lítil í albjóðlegum samanburði.

Í pessari grein veltum við fyrir okkur hversu miklu máli félags- og efnahagsleg staða foreldra skiptir í raun fyrir árangur íslenskra nemenda í PISA. Við munum færa rök fyrir pví að pær aðferðir sem hafa verið notaðar til að meta petta séu almennt óheppilegar og henti sérstaklega illa á Íslandi vegna pess hversu lítill breytileiki er í félags- og efnahagslegri stöðu í samanburði við heiminn yfirleitt. Hér draga aðferðirnar upp allt of jákvæða mynd, sem í raun er ósennileg pegar skoðaðar eru niðurstöður rannsókna á áhrifum félagslegrar stöðu á námsárangur.

\section{Félagsauður og námsárangur}

Á síðustu áratugum tuttugustu aldar beindu rannsakendur sjónum sínum í auknum mæli að félagslegum páttum og pví að skólar hefðu ekki pau jöfnunaráhrif sem talið hafði verið hvað varðaði aðstæður barna og að tryggja öllum börnum sömu möguleika á að ná góðum árangri í námi. Franski félagsfræðingurinn Pierre Bourdieu (1986) og bandaríski félagsfræðingurinn James Coleman (1988) settu báðir fram hugmyndir um félagsauð og mikilvægi hans fyrir námsgengi. Deir færðu rök fyrir pví að ákveðnum félagslegum ójöfnuði væri viðhaldið í samfélaginu og skólar einir og sér breyttu par litlu. Bourdieu (1986) taldi að hagur fólks lægi í tengslaneti pess og pannig gæeti fólk áorkað í sameiningu pví sem einstaklingurinn einn og sér væri illfær eða ófær um. Hann taldi að skólakerfið væri hluti af menningarlegu kerfi sem viðhéldi og upphæfi gildi og menningarauð efri stétta og væri einn peirra pátta sem gerðu peim sem tilheyrðu efri stétt kleift að halda stöðu sinni innan samfélagsins. Bæði nemendur sjálfir og kennarar peirra litu á pann menningarauð sem mótað hefði nemendur úr efri stéttum sem persónulega verðleika barnanna en pá pætti sem hefðu mótað börn úr lægri stéttum sem óæskilega og óviðkomandi skólastarfinu (Bourdieu og Passeron, 1990).

Á svipaðan hátt taldi Coleman (1988) að félagsleg tengsl fólks innan fjölskyldu og samfélags gætu haft margvísleg jákvæð áhrif á líf einstaklinga, ekki síst pegar kæmi að námslegum páttum. Coleman var einn höfunda skýrslunnar Equality of Educational Opportunity Study (EEOS) sem varð pó betur pekkt sem Coleman-skýrslan (e. The Coleman report). Skýrslan er byggð á gögnum úr umfangsmikilli bandarískri rannsókn sem tók til 4.000 skóla, 66.000 kennara og 600.000 nemenda î 1., 3., 6., 9. og 12. bekk. Í skýrslunni er pví haldið fram að aðeins $10 \%$ af breytileika í námsárangri nemenda megi skýra með páttum innan skóla og að flókið samspil félagslegra pátta hafi afgerandi áhrif á námsárangur. Pannig hafi skólar takmörkuð áhrif á árangur ef tekið er tillit til bakgrunns og félagslegra aðstæðna nemenda (Coleman o.fl., 1966).

Rannsóknin sem fjallað er um í Coleman-skýrslunni er af mörgum talin með áhrifamestu menntarannsóknum síðustu aldar. Рað er pó ekki vegna pess að hún sé gallalaus, hvorki pegar skoðuð er framkvæmd, úrvinnsla eða túlkun niðurstaðna, heldur frekar af pví að í kjölfarið fylgdu margar rannsóknir par sem námsárangur nemenda var skoðaður út frá fjölbreyttari sjónarhornum en áđur (Hill, 2017). Í framhaldi færði Coleman rök fyrir pví að sá mannauður, sem væri að finna innan fjölskyldu, p.e. menntun foreldra, væri pungavigtarafl í árangri barna í námi (Coleman og Hoffer, 1987; Coleman, Hoffer og Kilgore, 1982; Hoffer, Greeley og Coleman, 1985). Coleman taldi að flestir pættir í lífi barna væru háđir forráðamönnum peirra og pví hefði fjölskyldan, og 
sá mannauður sem finna mætti innan hennar, margvísleg áhrif á nám barna. Menntaðir foreldrar væru líklegri til pess að halda pví á lofti að gott gengi í námi væri lykillinn að velgengni og ýttu pannig undir nám barna sinna. Einnig taldi Coleman (1988) að betur menntaðir foreldrar hefðu meiri tíma og fjármagn og verðu pví meiri tíma með börnum sínum, auk pess sem peir væru líklegri til að mynda mikilvæg tengsl við vini barna sinna og foreldra peirra og byggðu pannig upp sameiginlega sýn og viðhorf í nærsamfélagi sínu. Með kenningum sínum um félagsauð færðu Coleman og Bourdieu kastljósið í menntarannsóknum að einhverju leyti frá pröngum námskrárlegum áherslum við skoðun á námsgengi nemenda og víkkuðu merkingu hugtaksins svo pað tæki einnig til áhrifa nærumhverfis og ýmissa félagslegra pátta sem er viðfangsefni pessarar greinar.

\section{Menntun foreldra}

Síðan Coleman og Bourdieu komu fram með kenningar sínar um félagsauð á níunda áratug síðustu aldar hafa fjölmargar rannsóknir sýnt fram á tengsl félagslegra bakgrunnspátta eins og menntunar foreldra við námsárangur barna (Davis-Kean, 2005; Haveman og Wolfe, 1995; Israel o.fl., 2001; Magnuson, 2007; Sirin, 2005; Steinberg, 1996; Thorlindsson, Bjarnason og Sigfusdottir, 2007). Fræðimenn hafa fært rök fyrir pví að börn menntaðra foreldra fái almennt betri tækifæri og pað stuðli síðan að betri árangri (Mullis, Rathge og Mullis, 2003). Til að mynda sýndu Israel o.fl. (2001) fram á að börn bandarískra foreldra par sem að minnsta kosti annað peirra var háskólagengið næðu betri árangri í stærðfræði og lestri en börn foreldra sem ekki væru háskólagengnir. Einnig komust Boardman, Powers, Padilla og Hummer (2002) að peirri niðurstöðu að börn bandarískra mæðra sem lokið höfðu að minnsta kosti framhaldsskóla stóðu sig betur í námi en börn mæðra sem ekki höfðu lokið framhaldskólaprófi.

Sumir fræðimenn telja menntaða foreldra líklegri en aðra til pess að styðja börnin sín námslega og vera í félagslegum tengslum við fólk í svipaðri stöðu sem deilir sömu viðhorfum (Steinberg, 1996). Hátt menntunarstig foreldra hafi pannig tilhneigingu til að endurspeglast 1 viðhorfi peirra til menntunar. Halle, Kurtz-Costes og Mahoney (1997) skoðuðu tengslin milli menntunar móður og námsárangurs barna. Í úrtakinu í rannsókn peirra voru fjölskyldur í lágstétt og fjölskyldur sem tilheyrðu minnihlutahópum. Í ljós kom að mæður með hærra menntunarstig höfðu meiri væntingar til barna sinna í námi og pað skilađi sér í betri námsárangri. Ýmsar rannsóknir benda til pess að menntun foreldra sé sá bakgrunnspáttur sem mest áhrif hafi á námsárangur barna. Foreldrar með hærra menntunarstig eru almennt líklegir til að búa við meira fjárhagslegt öryggi en aðrir og eru færir um að veita börnum sínum meira pegar kemur að páttum sem stuðla að árangri í námi auk pess sem peir eru betur í stakk búnir til að aðstoða börnin sín (Castro o.fl., 2015; Gutman og Eccles, 1999; Sirin, 2005). Sirin (2005) greindi 74 ólíkar rannsóknir á áhrifum félagslegs bakgrunns á námsárangur. Rannsóknirnar tóku til yfir hundrað púsund nemenda í 6.874 skólum. Um helmingur pessara rannsókna hafði menntun foreldra sem mælikvarða á félagslegan bakgrunn. Í ljós kom að af öllum páttum sem skoðaðir voru í safngreiningunni hafði félagslegur bakgrunnur sterkustu tengslin við námsárangur nemenda.

\section{Áhrif félags- og efnahagslegrar stöðu í PISA}

Ójöfnuður og áhrif hans á árangur nemenda hafa einnig verið skoðuð meðal pátttökupjóða í PISA. Martins og Veiga (2010) skoðuðu áhrif ójafnaðar á námsárangur nemenda í stærðfræði í 15 Evrópusambandslöndum sem tóku pátt í PISA. Niðurstöður peirra sýndu að finna mátti neikvæð áhrif af félagslegum ójöfnuði á árangur nemenda í PISA, par á meðal af menntunarstigi foreldra. Pannig sýndu Martins og Veiga (2010) fram á að áhrifin af menntun foreldra á námsárangur voru hvað mest á Norðurlöndum, Írlandi og í Stóra-Bretlandi. Niðurstöður sýndu að pótt almennur jöfnuður mældist hvað mestur á Norðurlöndum af pátttökupjóðum, til að mynda mun meiri en í Stóra-Bretlandi, voru áhrifin af menntun foreldra á námsárangur barna peirra samt töluverð. 
Dessar niðurstöður Martins og Veiga (2010) eru í töluverðu ósamræmi við pær ályktanir sem dregnar hafa verið af niðurstöðum PISA hér á landi (Almar M. Halldórsson o.fl., 2010, 2013; Menntamálastofnun, 2017) par sem félagsleg staða er talin skipta mjög litlu máli fyrir árangur nemenda. Til að mynda má sjá í skýrslu um helstu niðurstöður PISA 2012 að ekkert samband sé milli menntunarstigs foreldra eftir skólum og meðallæsis nemenda á stærðfræði, eða eins og pað er orðað „,a læsi grunnskólanemenda á stærðfræði við lok grunnskóla er á engan hátt háð menntunarstigi foreldra“" (Almar M. Halldórsson o.fl., 2013, bls. 65). Dannig töldu höfundar að menntunarstig skýrði 0\% af breytileika í meðallæsi milli skóla og að niðurstöður PISA sýndu pví að læsi íslenskra grunnskólanemenda á stærðfræði við lok grunnskóla væri á engan hátt hád menntunarstigi foreldra (Almar M. Halldórsson o.fl., 2013). Pessi niðurstaða Almars og félaga (2013) verður að teljast mjög forvitnileg í ljósi pess að mikil eða talsverð áhrif af menntun foreldra má finna í nánast öllum rannsóknum par sem skoðuð eru tengsl menntunar foreldra og námsárangurs barna peirra. Ætla má að foreldrar geti haft áhrif á námsárangur hér á landi rétt eins og gerist á öðrum Norðurlöndum, pá sérstaklega í ljósi pess að um svipuð samfélög er að ræða og ólíklegt að Ísland skeri sig að pessu leyti mjög úr.

Dessi óvenjulega niðurstaða, að félags- og efnahagsleg staða hafi lítil áhrif á Íslandi, kallar á nánari skoðun, meðal annars á peim breytum sem notaðar eru til að meta pessa pætti. Rutkowski og Rutkowski (2010) benda á að áreiðanleiki bakgrunnsbreyta í alpjóðlegum könnunum sé oft óviðunandi og taka par meðal annars dæmi um breytu sem notuð er í PISA og mælir efnisleg gæði. Í rannsókn peirra sem birt er premur árum síðar eru aftur settar fram efasemdir um áreiðanleika og réttmæti mælinga á efnislegum gæðum í PISA (Rutkowski og Rutkowski, 2013).

Mest notaða mæling á félags- og efnahagslegri stöðu pátttakenda í PISA-könnunum er ESCSstuðullinn (e. The PISA index of economic, social and cultural status) sem er samsettur úr premur breytum byggðum á svörum pátttakenda (OECD, 2017). Fyrsta breytan er einmitt sama breyta og Rutkowski og Rutkowski (2010, 2013) höfðu efasemdir um. Breytan er byggð á spurningum um efnisleg gæði á heimili, til að mynda hvort pátttakandi hafi eigið herbergi, aðgang að tölvu, fræðsluhugbúnaði, handbókum og orðabókum á heimili sínu. Breytan er kölluð HOMEPOS og eru atriðin 22 á listanum pau sömu í öllum löndum en framkvæmdaraðilar í hverju landi geta bætt við premur atriðum sem snerta efnisleg gæði og miðast við aðstæður viðkomandi lands.

Önnur breytan er mæling á menntun foreldra (PARED) og eru svör flokkuð samkvæmt ISCED 97 (OCED, 1999), sem er alpjóðleg mæling á formlegri menntun (e. International Standard Classification of Education). Formlegri prófgráđu foreldris með hærra menntunarstig er breytt í dæmigerðan fjölda ára í skóla. Dessi árafjöldi getur verið mismunandi eftir löndum pótt ISCEDskilgreiningar séu samræmdar milli landa. Priðja og síðasta breytan er mæling á atvinnustöðu foreldra, HISEI. Störf eru flokkuð samkvæmt alpjóðlegu flokkunarkerfi sem kallast ISCO-08 (e. International Standard Classification of Occupations). Hvort foreldri um sig fær ákveðið ISEIskor sem byggist á hversu mikið menntun hefur áhrif á tekjur fyrir störf. ISEI-skor eru reiknuð á sama hátt fyrir öll lönd sem taka pátt í PISA. Endanlega breytan er síðan HISEI, sem er ISEIskor pess foreldris sem fær hærri útkomu. Nánar má lesa um tæknilega útfærslu í skýrslu OECD (2017).

Töluverðir annmarkar eru á notkun pessara mælinga. Til að mynda er lítill breytileiki á breytunni sem mælir efnisleg gæði (HOMEPOS) á Norðurlöndum. Ísland er par ekki undantekning par sem nánast allir hér á landi hafa aðgang að peim hlutum sem par eru taldir upp. Breytan sem mælir menntun foreldra, PARED, hefur eitt tölugildi fyrir hvern ISCED-flokk í hverju landi. Í HISEI-breytunni tapast upplýsingar pegar sömu skor eru notuð í öllum pátttökulöndum. Við mat á PARED-breytunni og HISEI-breytunni er auk pess miðað við menntunar- og atvinnustöðu pess foreldris sem fær hærra gildi á menntunar- og atvinnukvarðanum. Á pennan hátt verður breytileiki minni, sérstaklega par sem tíðkast hjúskapur fólks af ólíkum mennta- og starfsstéttum. Degar kvarðarnir PARED og HISEI eru teknir saman í ESCS-breytuna er gert ráð fyrir að breyturnar hafi sömu áhrif á félags- og efnahagsstöðu í öllum pátttökulöndum, pað 
er sömu meginhlutahleðslur eru notaðar í öllum pátttökulöndunum. Dessi einföldun felur í sér vissa ónákvæmni pví ef meginhlutaskor eru reiknuð sérstaklega fyrir hvert land fyrir sig, pá fást hleðslur á bilinu 0,64-0,80 fyrir HOMEPOS, 0,75-0,85 fyrir PARED og 0,74-0,86 fyrir HISEI, sem gefur til kynna að ESCS-breytan mæli ekki pað sama á milli landa (OECD, 2017).

Færa má rök fyrir pví að skynsamlegra sé að skoða pessa bakgrunnspætti á einfaldari hátt par sem til grundvallar liggi nokkuð einfaldar breytur með skýrari merkingu. Hér munum við beina sjónum að ISCED-menntunarflokkum. Eðlilegt er að skoða breytur með skýra merkingu fyrst pegar samband félags- og efnahagslegrar stöðu við aðrar breytur pátttakenda er metið. Í kjölfarið má svo skoða hvort hægt sé að taka breyturnar saman til að einfalda framsetningu og túlkun niðurstaðna.

\section{Sérstaða Íslands}

Ætla má að skýringuna á sérstöðu Íslands pegar kemur að litlum áhrifum félags- og efnahagslegrar stöðu megi frekar rekja til peirra aðferða sem notaðar voru við greiningar og lítils breytileika í félags- og efnahagslegri stöðu en pess að áhrifin séu ekki til staðar. Í skýrslu Námsmatsstofnunar um PISA 2012 (Almar M. Halldórsson o.fl., 2013) eru ályktanir byggðar á samanburði skýringarhlutfalls $\left(R^{2}\right)$ fyrir samband bakgrunnsbreyta nemenda og árangurs pátttakenda í PISAkönnuninni. Skýringarhlutföll eru einnig áberandi í grein Reimer, Jensen og Kjeldsen (2018) í Northern Lights on TIMSS and PISA 2018. Dá má sjá að skýringarhlutföll fyrir samband félagsog efnahagslegra bakgrunnsbreyta við námsárangur eru gjarnan áberandi í skýrslum OECD um niðurstöður PISA-prófa. Skýringarhlutfall er fyrst og fremst góður mælikvarði á hversu pétt gagnapunktar raðast utan um spágildi samkvæmt línulegu aðhvarfslíkani, og pað getur í sumum tilfellum verið ágætur mælikvarði á praktíska pýðingu fylgnisambands. Skýringarhlutfall er pó ekki beinn mælikvarði á áhrifsstærð, sem í pessu tilfelli er hversu miklu máli félags- og efnahagsleg staða skiptir fyrir námsárangur einstaklings. Vandinn við skýringarhlutfall er að pað

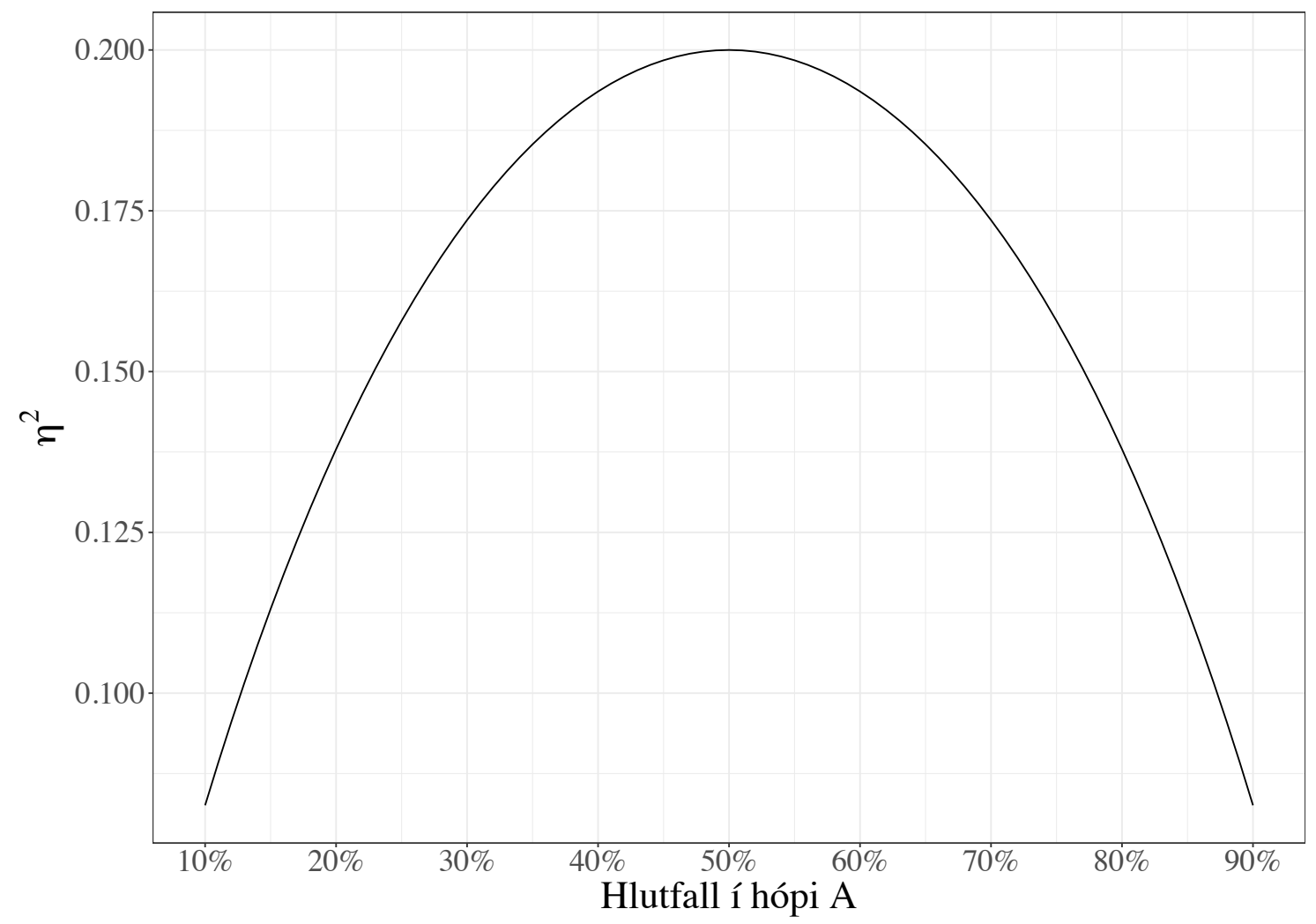

Mynd 1. Skýringarhlutfall sem fall af hlutfalli í hópi A með fastri áhrifastærð. 
er ekki síður háð breytileika á frumbreytu, sem í pessu tilfelli er félags- og efnahagsleg staða, en styrk sambandsins. Sé breytileiki í frumbreytunni lítill leiðir pað til lægra skýringarhlutfalls par sem $R^{2}$ er aðallega mæling á mátgæðum (Faraway, 2002).

Tökum einfalt dæmi sem sýnir pessa vankanta, par sem notað er $\eta^{2}$ sem er pað sem $R^{2}$ er kallað pegar frumbreytan er flokkabreyta. Við erum með frumbreytu sem tekur gildin A og B og tölulega útkomubreytu Y. A og B gætu verið mismunandi lönd og Y árangur í einhverri könnun sambærilegri við PISA. Í báðum löndum er Y normaldreifð með staðalfrávikið 1 en nemendur í landi B eru einum hærri að meðaltali en nemendur í landi A á breytunni Y. Ef hópar nemenda sem tóku pátt eru jafnstórir í báđum löndunum, pá er Y blönduð normaldreifing með dreifni 1,25. Við pessi skilyrði yrði $\eta^{2}=0,2$. Ef hlutfallið í hópunum væri aftur á móti ójafnara, til að mynda $20 \%$ í landi B en $80 \%$ í landi A, pá yroi $\eta^{2}=0,138$ en petta má sjá á mynd 1 . Myndin sýnir pýðisgildi $\eta^{2}$ sem fall af hlutfalli í hvorum hópi, pað er hvað $\eta^{2}$ er miðað við að mismunandi hlutfall nemenda búi í landi A. Með öðrum orðum pýðir petta að ef 50\% nemenda búa í landi A og 50\% í landi B, pá skýrir upprunaland 20\% af breytileika í Y. Ef 80\% ættu heima í landi A en $20 \%$ í landi B bá skýrir upprunalandið 13,8\% af breytileika í Y. Í báđum tilfellum er munur á meðalárangri eftir landi nákvæmlega sá sami og eina ástæðan fyrir ólíkum skýringarhlutföllum er mismunandi stærð hópa.

Баð sem petta dæmi hér að framan sýnir okkur um notkun skýringarhlutfalls við að meta áhrif félags- og efnahagslegrar stöðu er að væri meiri breytileiki í peirri breytu á Íslandi, t.d. hærra hlutfall foreldra með enga frekari menntun eftir grunnskóla, pá gæti pað haft áhrif á skýringarhlutfall. Höfundar pessarar greinar vilja halda pví fram að pegar öðrum leiðum við greiningar sé beitt megi sjá samanburðarhæf tengsl menntunar foreldra við námsárangur barna. Pá komi í ljós að pau séu sterkari en oft er haldið fram og mjög svipuð og annars staðar á Norðurlöndum.

Í ljósi framgreindrar umræðu eru settar fram tvær spurningar sem leiða rannsóknina:

a) Er samband menntunarstigs foreldra og námsárangurs barna í PISA á Íslandi sambærilegt og á öðrum Norðurlöndum?

b) Er lágt skýringarhlutfall félags- og efnahagsstöðu foreldra á frammistöðu nemenda í PISA til marks um lítil tengsl við námsárangur eða lítinn breytileika í félags- og efnahagsstöðu á Íslandi?

\section{Aðferð}

Dessi rannsókn er byggð á gögnum úr PISA (e. Program for International Student Assessment), könnun OECD sem framkvæmd var árið 2015. Rannsóknin er alpjóðleg samanburðarrannsókn á frammistöðu 15-16 ára unglinga í lesskilningi, stærðfræðilæsi og náttúrufræðilæsi. Í mörgum pátttökulöndum eru lok skyldunáms við 15-16 ára aldur og í peim löndum, par með talið á Íslandi, sýnir könnunin stöðu nemenda við lok grunnskóla. Rannsóknin er framkvæmd priðja hvert ár og hefur Ísland verið pátttakandi frá pví að könnunin var fyrst lögð fyrir árið 2000. Í hverri fyrirlögn er aðaláhersla á einn af peim premur páttum sem PISA mælir og árið 2015 var áherslan á náttúrufræðilæsi. Allir nemendur svara tveggja stunda könnun og var að minnsta kosti ein klukkustund ætluð læsi í náttúruvísindum (Menntamálastofnun, 2017). Könnunin var lögð fyrir í 72 löndum, par af 34 OECD-löndum og 38 löndum utan OECD (OECD, 2018). Greiningin í pessari rannsókn einskorðaðist við Norðurlöndin fimm; Noreg, Danmörku, Svípjóð, Finnland og Ísland. 


\section{Framkvæmd PISA}

Af hálfu OECD eru settar strangar reglur um framkvæmd PISA-könnunarinnar. Sérstakir framkvæmdaraðilar, sem eru tilnefndir af menntamálaráðuneyti hvers lands, hafa pað hlutverk að sjá til pess að farið sé að settum reglum. Á Íslandi er framkvæmdin í höndum Menntamálastofnunar. Í flestum löndum sem taka pátt í PISA eru valin úrtök með um pað bil fjögur til sex púsund pátttakendum. Í fámennari löndum eins og á Íslandi, par sem að jafnaði eru færri en 4000 nemendur í hverjum skólaárgangi, er ekki valið úrtak heldur er óskað eftir pátttöku allra nemenda sem uppfylla aldursskilyrði. Árið 2015 var könnunin í fyrsta skipti lögð fyrir rafrænt. Pátttakendur svara könnun sem inniheldur blandaðar fjölvalsspurningar auk opinna spurninga par sem rita parf svörin. Samtals eru í könnuninni 183 spurningar um læsi á náttúruvísindi, læsi á stærðfræði er metið með 69 spurningum og lesskilningur með 88 spurningum. Hver nemandi svarar aðeins hluta af spurningunum. Allir nemendur fá tvær klukkustundir til að svara könnuninni. Degar nemendur hafa lokið könnuninni eru peir beðnir að svara spurningalista um ýmsa bakgrunnspætti, viðhorf sitt til náms og framtíðaráform (Menntamálastofnun, 2017).

\section{Pátttakendur}

Pátttakendur í pessari rannsókn voru allir nemendur á Norðurlöndum sem tóku pátt í PISArannsókninni árið 2015. Í töflu 1 má sjá fjölda pátttakenda, skipt eftir landi og menntunarflokki foreldra og byggt er á svörum pátttakenda. Afar fáir pátttakendur eiga foreldra með mjög litla skólagöngu sem falla í menntunarflokka 0 og 1 og var peim pátttakendum pví sleppt í greiningum (sjá nánari umfjöllun í kaflanum um breytur). Sumir pátttakendur svöruðu aðeins til um menntun annars foreldris. Ef aðeins lágu fyrir upplýsingar um menntun annars foreldris taldist sú menntun sjálfkrafa hærra menntunarstig foreldris í greiningum hér á eftir.

Tafla 1. Fjöldi pátttakenda eftir landi og menntunarstigi foreldris.

\begin{tabular}{llllllllllll}
\hline & \multicolumn{1}{c}{ Menntun módur } & \multicolumn{1}{c}{ Menntun föður } \\
& DAN & FIN & ÍSL & NOR & SVÍ & DAN & FIN & ÍSL & NOR & SVÍ \\
\hline Flokkur 0 & 118 & 31 & 23 & 37 & 85 & 88 & 61 & 40 & 32 & 86 \\
Flokkur 1 & 169 & 36 & 0 & 31 & 52 & 156 & 82 & 0 & 29 & 70 \\
Flokkur 2 & 1224 & 186 & 455 & 240 & 331 & 1815 & 322 & 430 & 271 & 456 \\
Flokkur 3 & 693 & 651 & 131 & 233 & 442 & 889 & 962 & 283 & 320 & 554 \\
Flokkur 4 & 477 & 613 & 623 & 1366 & 852 & 386 & 508 & 728 & 1580 & 962 \\
Flokkur 5 & 829 & 1320 & 208 & 1959 & 1140 & 806 & 1359 & 390 & 1382 & 1017 \\
Flokkur 6 & 3372 & 2929 & 1789 & 1329 & 2266 & 2637 & 2397 & 1305 & 1471 & 1921 \\
Vantar & 279 & 116 & 142 & 261 & 290 & 384 & 191 & 195 & 371 & 392 \\
Samtals & 7161 & 5882 & 3371 & 5456 & 5458 & 7161 & 5882 & 3371 & 5456 & 5458 \\
\hline
\end{tabular}

\section{Breytur}

\section{Menntunarflokkar}

Svör pátttakenda um menntun foreldra eru flokkuð eftir alpjóðlega ISCED-flokkunarkerfinu um menntun, International Standard Classification of Education, frá 1997 sem UNESCO notar til að flokka menntun einstaklinga. ISCED-flokkunarkerfið hefur verið uppfært frá 1997 en OECD notar enn pá útgáfu sem var í gildi pegar fyrsta PISA-könnunin var lögð fyrir árið 2000 (sjá OECD, 1999). Eftir að menntunarstig foreldra pátttakenda hefur verið flokkað samkvæmt ISCED 1997-kerfinu er menntun aftur raðað í númeraða flokka með númer á bilinu 0 til 6, eins og sjá má í töflu 2. 
Tafla 2. Menntunarflokkun í gögnum OECD.

\begin{tabular}{lll}
\hline Flokkur & ISCED & Lýsing \\
\hline 0 & & Engin formleg menntun \\
1 & 1 & Fyrra stig grunnmenntunar \\
2 & 2 & Seinna stig grunnmenntunar \\
3 & $3 \mathrm{~B}, 3 \mathrm{C}$ & Iðn- og starfsmenntun á framhaldsskólastigi \\
4 & $3 \mathrm{~A}, 4$ & Stúdentspróf, iðnmeistarapróf, viðbótarnám á framhaldsskólastigi (en ekki \\
5 & $5 \mathrm{~B}$ & á háskólastigi) \\
6 & $5 \mathrm{~A}, 6$ & Ölarfsmenntun á háskólastigi án háskólagrádu \\
\hline
\end{tabular}

PISA-skor pátttakenda

Árangur hvers nemanda í PISA-könnuninni er metinn á grundvelli svarferlakenninga (e. itemresponse theory). Segja má að árangur nemanda sé mældur á mælikvarða sem er óháđur prófatriðum og árangri annarra próftaka í hverri fyrirlögn (Mazzeo og von Davier, 2013). Niðurstöður eða skor pátttakenda eru pví samanburðarhæf á milli landa, hópa og á ólíkum tímum. Til að mynda er hægt að bera niðurstöðu nemenda í tilteknu landi saman við niðurstöðu nemenda í sama landi premur árum fyrr. Einkunnakvarðanum í PISA-rannsókninni er jafnframt skipt í hæfniprep par sem ákveðin hæfni er skilgreind á hverju prepi fyrir sig. Hæfniprepin eru alls sex, par sem stigvaxandi kröfur eru frá prepi 1 upp í 6 . Niðurstöður rannsókna sem hafa verið gerðar á framförum nemenda benda til pess að hægt sé að nota 30 stig sem gróft viðmið um meðalframför nemenda á einu skólaári (Menntamálastofnun 2017; OECD, 2017).

\section{Greining}

Markmið PISA er ekki að meta frammistöðu einstakra pátttakenda heldur skólakerfa. Prófin eru til pess fallin að meta vítt svið frekar en að ná miklum áreiðanleika í mati á árangri einstakra nemenda. Hver nemandi fær pví úrtak úr prófinu en tekur ekki prófið í heild. Heildarárangur er síðan tilreiknaður (e. imputed) úr peim svörum sem pátttakandi gaf. Dar sem óvissa fylgir tilreiknun fær hver nemandi 10 ólík tilreiknunargildi með slembitölu úr villulið. Dreifni á milli tilreiknunargilda er síðan notuð til að reikna tilreiknunaróvissuna inn í endanlega staðalvillu (OECD, 2017).

Eins og áður sagði er PISA pýðiskönnun á Íslandi en víðast erlendis er úrtakið lagskipt. Alls staðar er úrtakið klasað pannig að gert er rád fyrir að nemendur í sama skóla séu líkari en nemendur í ólíkum skólum. Einnig er um að ræða úrtak úr endanlegu pýði pannig að flóknara er að meta úrtakadreifingu PISA-úrtaks en úrtakadreifingu einfalds slembiúrtaks. Til pess að reikna staðalvillur er útgáfa Fays af endurtektarvigtum (e. balanced repeated replication) notuð en OECD mælir með notkun hennar (OECD, 2009). Til að vinna samtímis með tilreiknunargildi og endurtektarvigtir var R-pakkinn Intsvy (útg. 2.3, Caro og Biecek, 2017) notaður við útreikninga meðaltala og staðalvillna. Einnig var pakkinn notaður til að reikna vigtuð hlutföll eftir hæfniprepum. Staðalvillur mismuna meðaltala voru handreiknuð upp úr staðalvillum meðaltala. Öll tölfræðiúrvinnsla fór fram í R (útg. 3.4.4).

\section{Niðurstöður}

Á myndum 2, 3 og 4 sést meðalárangur og 95\% öryggisbil fyrir árangur í stærðfræðilæsi, lesskilningi og náttúrufræðilæsi í PISA á Norðurlöndunum fimm eftir menntunarstigi móður og föður. Dar sést glögglega að meðalárangur pátttakenda í PISA var jafnan betri eftir pví sem menntunarstig foreldra var hærra. Menntun móður og föður hefur eins eða mjög ápekkt samband 


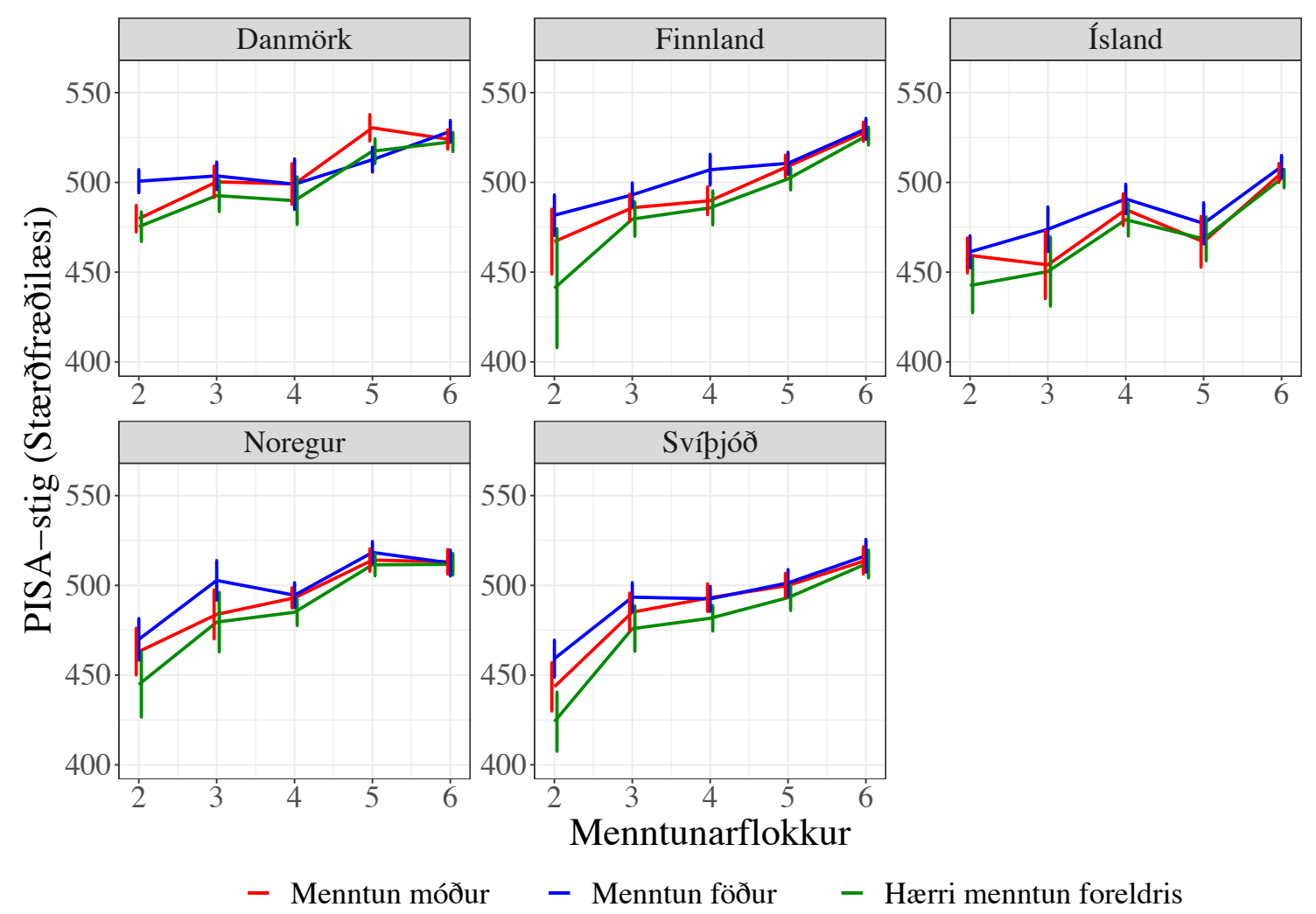

Mynd 2. Meðalárangur í stærðfræðilæsi eftir menntunarflokki móður og föður ásamt hærri menntunarflokki foreldris.

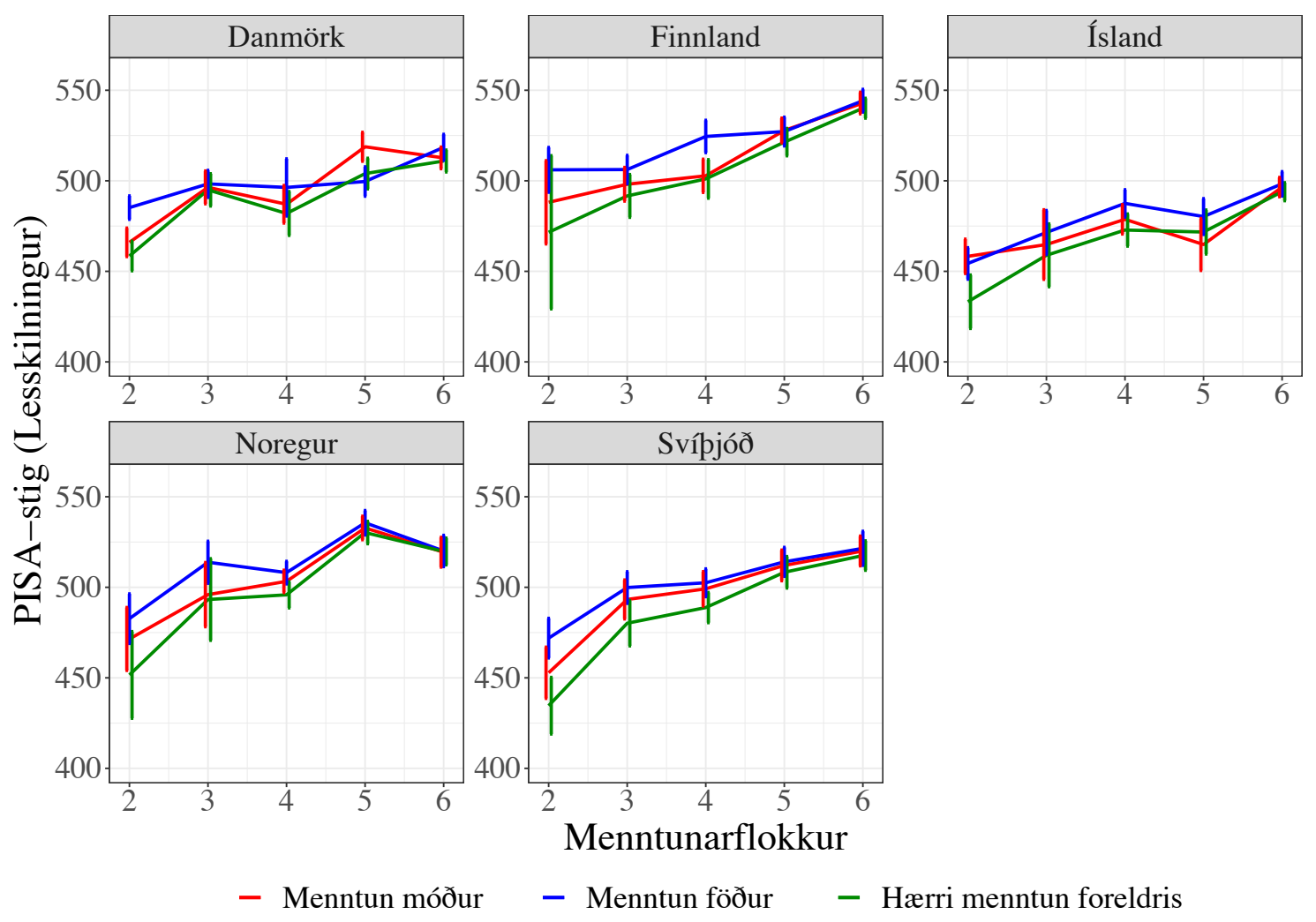

Mynd 3. Meðalárangur í lesskilningi eftir menntunarflokki móður og fỏður ásamt hærri menntunarflokki foreldris. 


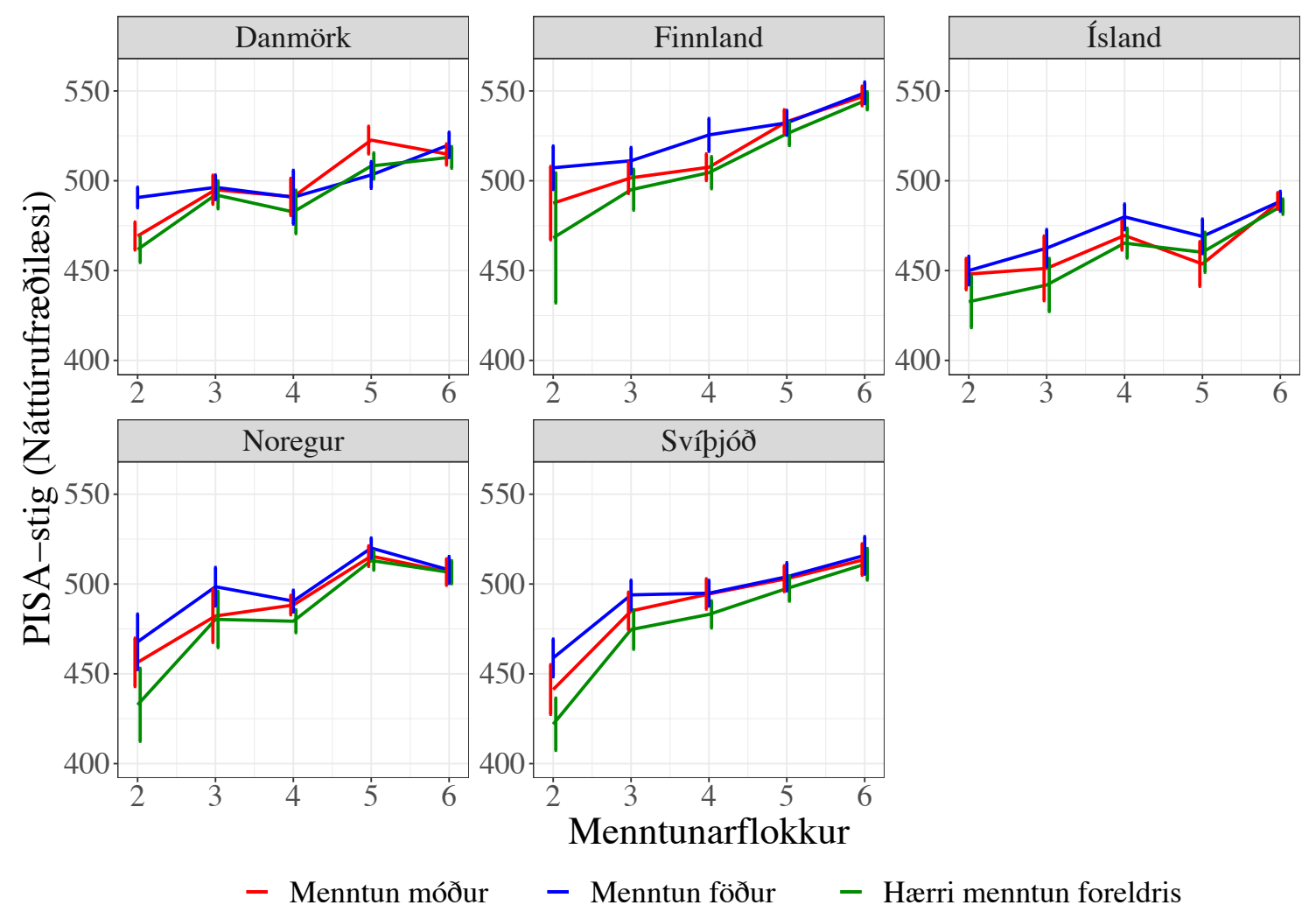

Mynd 4. Meðalárangur í náttúrufræðilæsi eftir menntunarflokki móður og föður ásamt hærri menntunarflokki foreldris.

við námsárangur barns. Bæði á milli landa og námsgreina er pað gegnumgangandi að munurinn á árangri barna mest og minnst menntuðu foreldranna er meiri ef horft er á hærra menntunarstig foreldris en ef aðeins er horft á menntunarstig móður eða föður.

Breidd öryggisbilanna fer eftir fjölda í hverjum hópi og breytileika innan hans. Óvissa í mati verður meiri ef hópar eru fámennir eða ef mikill breytileiki er innan hópsins. Mikil óvissa í mati á meðalárangri barna finnskra foreldra í menntunarflokki 2 virðist frekar stafa af pví að pátttakendur úr peim flokki eru fáir en að breytileiki sé sérstaklega mikill. Rétt er að hafa í huga að par sem um stigskipt og vigtuð úrtök er að ræða er skipting pátttakendahópsins ekki í hlutfalli við skiptingu pýðisins. Meðalstigafjöldi eftir hæsta menntunarstigi foreldris ásamt fjölda pátttakenda og staðalfráviki kemur fram í töflu 3 . 
Tafla 3. Meðaltöl og staðalfrávik PISA-stiga pátttakenda eftir hærri menntunarflokki foreldris.

\begin{tabular}{|c|c|c|c|c|c|c|c|c|c|c|}
\hline & \multicolumn{2}{|c|}{ Danmörk } & \multicolumn{2}{|c|}{ Finnland } & \multicolumn{2}{|c|}{ Ísland } & \multicolumn{2}{|c|}{ Noregur } & \multicolumn{2}{|c|}{ Svíbjód } \\
\hline & M & Sf & M & Sf & M & Sf & M & Sf & M & Sf \\
\hline \multicolumn{11}{|c|}{ Stærðfræðilæsi } \\
\hline Mf 2 & 475 & 74,8 & 441 & 85,6 & 443 & 92,5 & 445 & 82,2 & 424 & 78,2 \\
\hline Mf 3 & 493 & 76,0 & 480 & 76,9 & 450 & 87,4 & 480 & 85,8 & 476 & 76,1 \\
\hline Mf 4 & 490 & 82,1 & 486 & 77,3 & 479 & 82,7 & 485 & 80,5 & 482 & 81,7 \\
\hline Mf 5 & 517 & 75,8 & 502 & 76,0 & 469 & 86,3 & 511 & 79,7 & 493 & 82,6 \\
\hline Mf 6 & 522 & 79,5 & 526 & 81,4 & 502 & 93,8 & 512 & 88,2 & 512 & 90,9 \\
\hline \multicolumn{11}{|c|}{ Lesskilningur } \\
\hline Mf 2 & 458 & 80,6 & 472 & 107,0 & 433 & 98,4 & 452 & 99,8 & 435 & 94,0 \\
\hline Mf 3 & 495 & 82,6 & 492 & 90,9 & 459 & 93,1 & 493 & 102,1 & 480 & 90,3 \\
\hline Mf 4 & 482 & 92,0 & 501 & 92,2 & 473 & 90,5 & 496 & 94,0 & 489 & 92,9 \\
\hline Mf 5 & 504 & 81,3 & 521 & 88,7 & 472 & 89,4 & 530 & 91,0 & 508 & 92,2 \\
\hline Mf 6 & 511 & 86,3 & 540 & 92,4 & 494 & 101,2 & 520 & 102,7 & 518 & 101,4 \\
\hline \multicolumn{11}{|c|}{ Náttúrufræðilæsi } \\
\hline Mf 2 & 462 & 80,2 & 468 & 100,3 & 433 & 90,3 & 433 & 92,7 & 422 & 87,5 \\
\hline Mf 3 & 492 & 83,2 & 495 & 91,7 & 442 & 82,0 & 480 & 93,3 & 475 & 88,5 \\
\hline Mf 4 & 483 & 94,4 & 505 & 92,6 & 465 & 81,6 & 479 & 89,6 & 483 & 91,7 \\
\hline Mf 5 & 508 & 84,6 & 526 & 91,6 & 460 & 82,5 & 513 & 89,7 & 498 & 93,9 \\
\hline Mf 6 & 513 & 90,1 & 545 & 95,2 & 486 & 93,2 & 507 & 101,3 & 511 & 104,4 \\
\hline
\end{tabular}

$M f=$ menntunarflokkur, $M=$ meðaltal, $S f=$ staðalfrávik

Munur á árangri nemenda eftir menntun foreldra kemur skýrt fram alls staðar á Norðurlöndum. Ef niðurstöður PISA í stærðfræðilæsi eru skoðaðar fyrir Noreg sést í töflu 3 að töluverður munur var á meðalskori pátttakenda sem áttu foreldra í lægsta menntunarflokki $(M=445, S f=82,2)$ og meðalskori pátttakenda sem áttu foreldra í hæsta menntunarflokki $(M=512, S f=88,2)$. Sams konar niðurstöður má sjá hjá íslenskum pátttakendum í stærðfræðilæsi, par munaði 59 stigum á meðalskori peirra pátttakenda sem áttu foreldra í lægsta menntunarflokki $(M=443, S f=92,5)$ og peirra sem áttu foreldra í hæsta menntunarflokki $(M=502, S f=93,8)$. Dessi munur samsvarar tveimur skólaárum ef notuð eru viðmið OECD sem leggur 30 stig að jöfnu við meðalframför nemenda á einu skólaári. Samsvarandi mun mátti einnig sjá hjá íslensku pátttakendunum í lesskilningi og náttúrufræðilæsi. Í lesskilningi munaði sem samsvarar rúmum tveimur skólaárum á árangri pátttakenda sem áttu foreldra í hæsta og lægsta menntunarflokki og munurinn var 1,8 ár í náttúrufræðilæsi.

Raunar má sjá á 95\% öryggisbilum í töflu 4 að alls staðar var vel marktækur munur á meðalframmistöðu peirra sem áttu foreldra sem aðeins höfðu lokið grunnskólamenntun og meðalframmistöðu pátttakenda sem áttu háskólamenntaða foreldra. Рað á við um allar prjár greinarnar sem prófaðar eru, stærðfræðilæsi, náttúrufræðilæsi og lesskilning, og á við alls staðar á Norðurlöndum. Sé munurinn á frammistöðu pátttakenda sem eiga foreldra sem hafa lokið grunnskólaprófi og peirra sem eiga háskólamenntaða foreldra skoðaður sést að munurinn samsvarar allt frá framförum á einu og hálfu ári upp í pað sem samsvarar framförum á tæpum premur skólaárum. 
Tafla 4. Mismunur á árangri pátttakenda sem eiga foreldra í menntunarflokki 2 og 6 , ásamt 95\% öryggisbilum fyrir mismuninn og mun mældum í skólaárum.

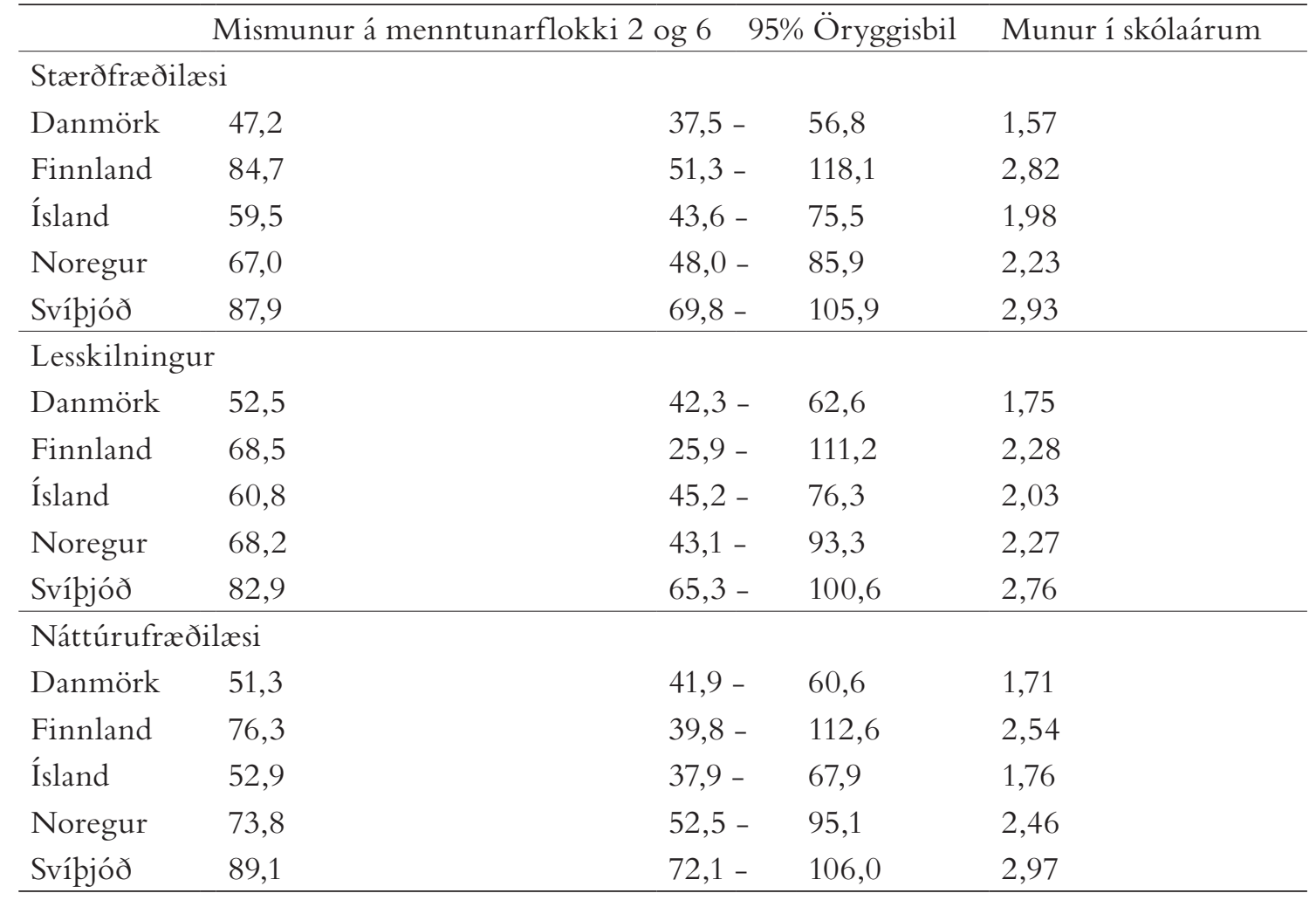

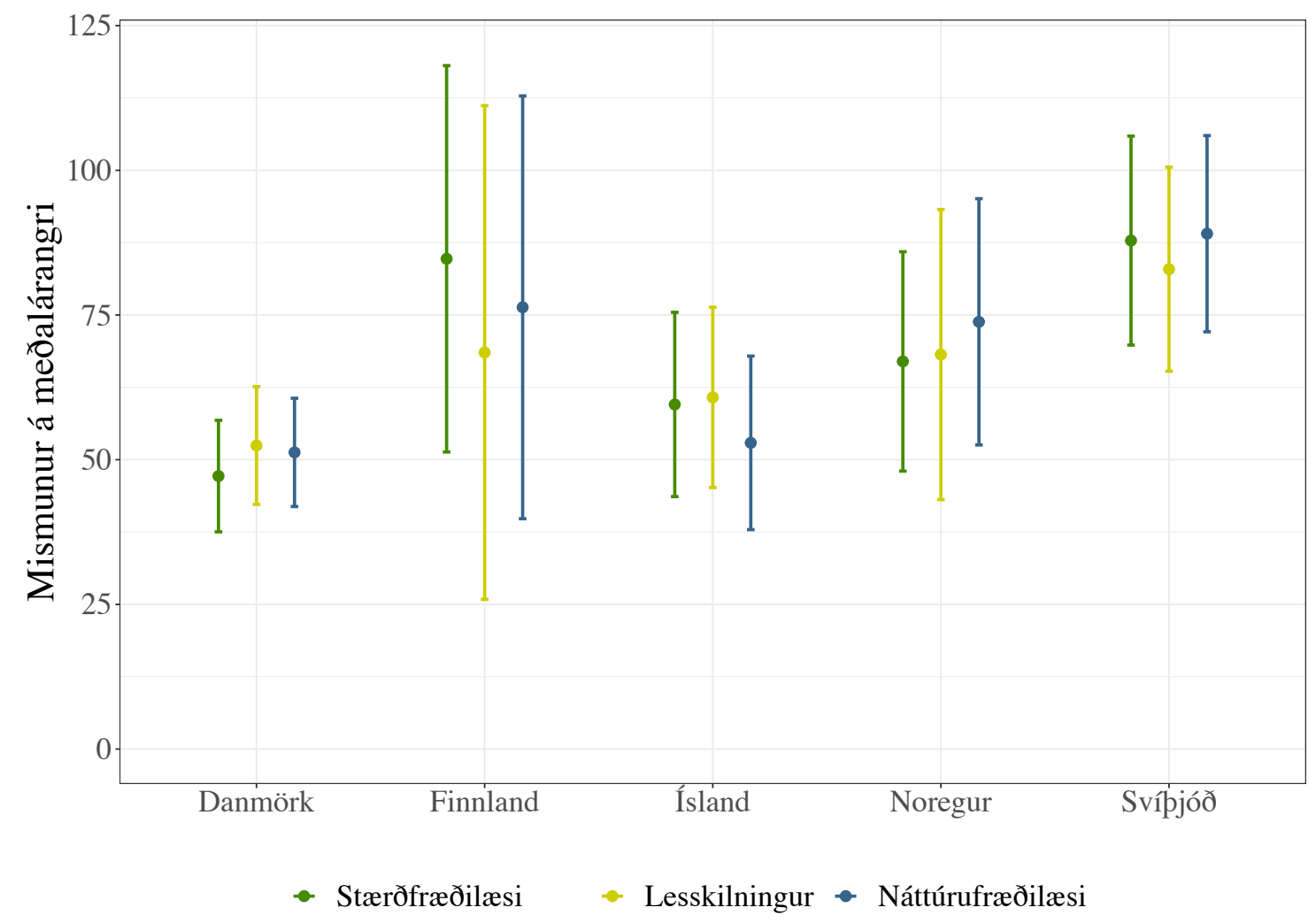

Mynd 5. Mismunur á meðalárangri barna foreldra í menntunarflokkum 2 og 6 í stærðfræði, lestri og náttúrufræði eftir löndum með 95\% öryggisbilum. 

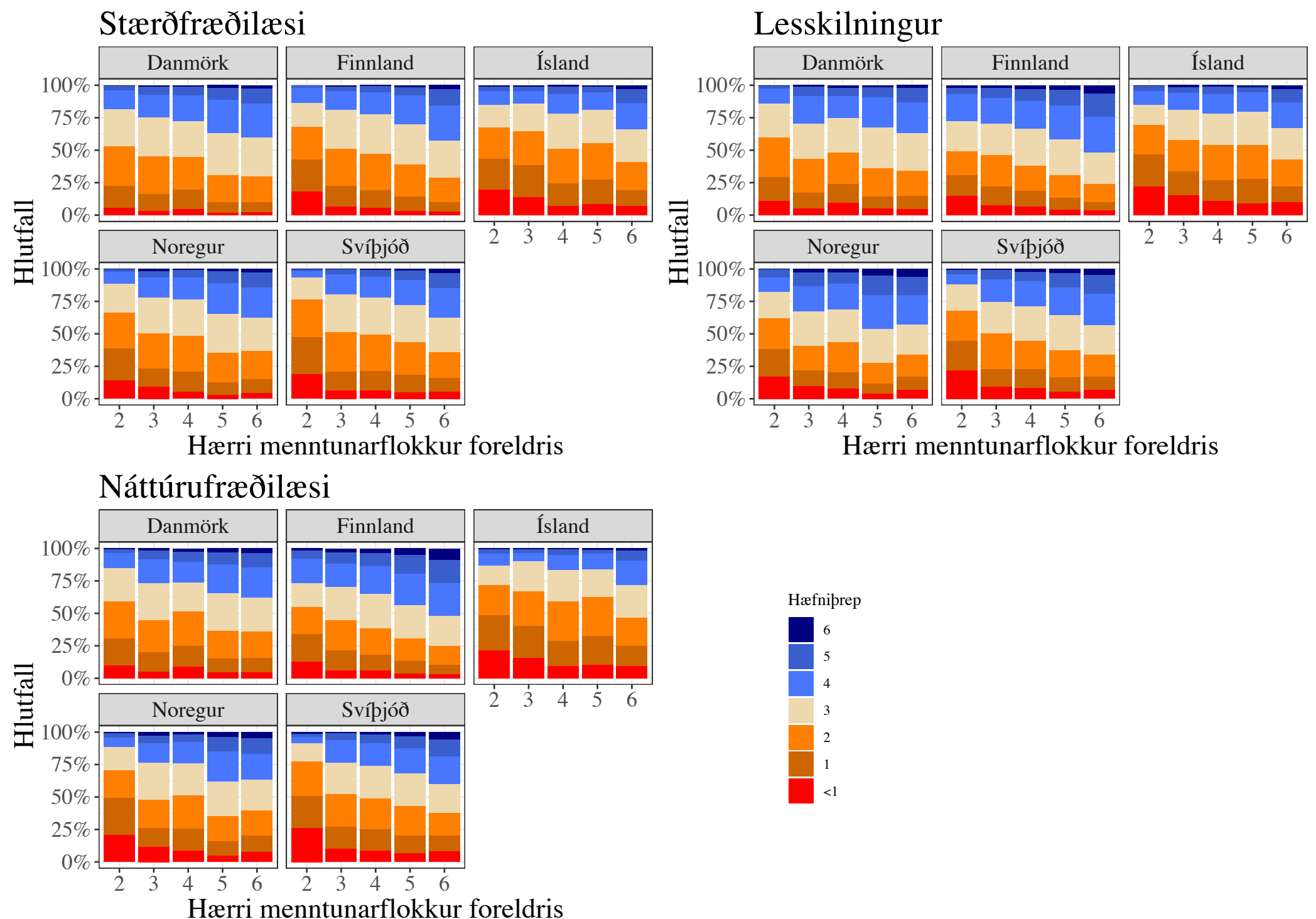

Mynd 6. Skipting nemenda á hæfniprep í stærðfræði, lestri og náttúrufræði eftir hærri menntun foreldris. 
Ísland sker sig ekki sérstaklega úr meðal Norðurlandanna ef horft er á pennan mismun. Á mynd 5 sést munur á meðalárangri barna grunn- og háskólamenntaðra foreldra í öllum premur námsgreinunum ásamt 95\% öryggisbilum og pað sést greinilega að Ísland hefur enga sérstöðu.

Árangur nemenda eftir menntun foreldra má einnig skoða út frá hlutfalli sem fellur á hvert hæfniprep í PISA. Á mynd 6 sést glögglega að eftir pví sem menntun foreldra eykst fjölgar pátttakendum hlutfallslega í öllum efri hæfniprepum og fækkar jafnframt í lægri hæfniprepum. Dannig sést að ef foreldri er í menntunarflokki 6 eru hlutfallslega fleiri pátttakendur sem flokkast á hæfniprepi 5 og 6 ef borið er saman við lægri menntunarstig foreldris. Petta á við um allar prjár prófgreinarnar í PISA.

Niðurstöður allra peirra greininga sem gerðar hafa verið hér að framan ber að sama brunni; talsverður munur er á getu íslenskra nemenda eftir menntun foreldra. Dað er munur á meðaltölum og líkur á að nemar flokkist á hærri hæfnisprep aukast eftir pví sem menntun foreldra er meiri. Börn foreldra sem einungis eru með grunnmenntun eru að jafnaði um tveimur skólaárum á eftir börnum sem eiga foreldra með háskólamenntun í lesskilningi og stærðfræðilæsi og 1,76 árum í náttúrufræðilæsi. Detta verður að teljast umtalsverður munur á árangri.

\section{Umræða}

Markmið pessarar rannsóknar var að skoða samband menntunar foreldra og árangurs barna peirra í PISA og hvort petta samband á Íslandi er frábrugðið pví sem gerist annars staðar á Norðurlöndum. Degar fyrri rannsóknir um petta efni eru skoðaðar sést að pví hefur verið haldiðá lofti að pjóðfélagsstaða skipti minna máli á Íslandi en í nokkru öðru pátttökulandi PISA. Petta má til að mynda sjá í skýrslum um íslenskar niðurstöður PISA 2012 og 2015 (Almar M. Halldórsson o.fl., 2013; Menntamálastofnun, 2017). Niðurstöður okkar greininga benda hins vegar til pess að alls staðar á Norðurlöndum sé umtalsverður munur á meðalárangri pátttakenda sem eiga foreldra sem eingöngu hafa grunnskólamenntun og peirra sem eiga foreldra með háskólamenntun. Sé pessi munur settur í samhengi við meðalframfarir nemenda á ári pá munar einu og hálfu skólaári á pessum hópum par sem munurinn er minnstur en tæpum premur skólaárum par sem hann er mestur. Detta pýðir í raun að meðalárangur barna í 10. bekk sem eiga foreldra sem eingöngu hafa grunnskólamenntun ætti að vera svipaður og meðalárangur barna í 7. bekk sem eiga foreldra með háskólamenntun. Á Íslandi er pessi munur í kringum tvö ár í lesskilningi og stærðfræðilæsi en heldur minni í náttúrufræðilæsi. Рað býðir að nemendur sem eiga foreldra með grunnmenntun eru að meðaltali á svipuðum slóðum í 10. bekk og nemendur sem eiga háskólamenntaða foreldra eru í 8. bekk.

Niðurstöður sýna einnig skýrt að pegar menntunarstig foreldra hækkar fjölgar pátttakendum hlutfallslega á hæstu hæfniprepunum og fækkar á peim lægri. Detta hlýtur að vera sérstakt áhyggjuefni par sem rannsóknir hafa sýnt tengsl árangurs sem mældur er í hæfniprepum í PISA og pess að ljúka námi í framhaldsskóla (Schleicher, 2007), og í danskri langtímarannsókn fundust tengsl milli slakrar útkomu í lesskilningi í PISA og pess að hætta námi í framhaldsskóla (Jensen og Andersen, 2006). Fischbach, Keller, Preckel og Brunner (2013) komust að peirri niðurstöðu, eftir að hafa skoðað gögn um nemendur í Lúxemborg, að hæfniprepin í PISA spáðu fyrir um árangur í námi, niðurstöðu á lokaprófum og hvort nemendur færðust eðlilega á milli bekkjardeilda eða pyrftu að endurtaka bekk.

Баð samband sem kom fram milli lengri menntunar foreldra og aukins árangurs nemenda í PISA 2015 var jákvætt alls staðar á Norðurlöndum pó pað hafi verið eitthvað mismunandi milli landa. Í Finnlandi batnaði árangur nemenda nokkuð jafnt og pétt eftir pví sem menntunarflokkur foreldris hækkaði á meðan ekki var skýr munur á börnum foreldra í menntunarflokkum 5 og 6 í Danmörku og Noregi, auk pess sem börn foreldra í menntunarflokki 5 á Íslandi náðu verri árangri en börn foreldra í menntunarflokki 4. Dessi munur var pó ekki mikill í hlutfalli við staðalvillu pannig að hugsanlega getur hann skýrst af úrtakadreifingu. Einnig er vel hugsanlegt 
að pátttakendur á Íslandi hafi ekki skilið á milli starfsmenntunar í háskóla og annars háskólanáms, en í flokk 5 fer starfsmenntun á háskólastigi sem ekki lýkur með háskólagráðu. Starfsnám á háskólastigi er hvorki algengt né áberandi á Íslandi og pví líklegt að pátttakendur geri ekki greinarmun par á. Einnig mátti sjá, pegar sambandið milli árangurs sænskra pátttakenda í PISA og menntunar foreldra peirra var skoðað, að mikið ris í meðalárangri var frá menntunarflokki 2, en par voru peir sem aðeins höfðu lokið grunnskólaprófi, en minna ris eftir pað. Líklegt má telja að nokkur fjöldi innflytjenda falli í menntunarflokk 2, en í Svípjóð eru hlutfallslega margir innflytjendur miðað við hin Norðurlöndin. Námsgengi barna innflytjenda gæeti mótast ekki aðeins af menntun foreldra heldur einnig vanda tengdum tungumáli.

Dó að sambandið á milli menntunar foreldra og árangurs pátttakenda í PISA hafi ekki verið nákvæmlega eins alls staðar á Norðurlöndum má almennt segja að aukin menntun foreldra tengist betri árangri pátttakenda í PISA. Niðurstöður benda til pess að á Norðurlöndum séu töluverð tengsl milli menntunar foreldra og árangurs pátttakenda. Dessar niðurstöður eru í samræmi við fjölda rannsókna á síðustu áratugum sem sýnt hafa tengsl menntunar foreldra við námsárangur barna peirra (Castro o.fl., 2015; Davis-Kean, 2005; Haveman og Wolfe, 1995; Israel o.fl., 2001; Magnuson, 2007; Mullis o.fl., 2003; Sirin, 2005; Thorlindsson o.fl., 2007). Sú sérstaða sem haldið hefur verið fram, að á Íslandi séu tengsl menntunar foreldra við námsárangur barna hverfandi, er pví miður ekki rétt. Niðurstöður okkar sýna að pegar öðrum aðferðum en skýringarhlutfalli er beitt við greiningu kemur samband á milli menntunar foreldra og árangurs barna peirra skýrt fram.

Niðurstöður pessarar rannsóknar sýna glöggt hættuna við að túlka skýringarhlutfallið $\left(R^{2}\right)$ sem áhrifastærð og sýna að pað er ekki góður valkostur pegar skoða á samband námsárangurs barna og félags- og menntunarlegrar stöðu foreldra peirra. Sérstaklega parf að hafa í huga áhrif breytileika 1 félags- og efnahagslegri stöðu á niðurstöðuna, pví sambandið er vanmetið ef breytileiki er lítill. Ef breytileikinn væri meiri á Íslandi, til að mynda ef hærra hlutfall foreldra hefði aðeins grunnskólamenntun, pá yrði skýringarhlutfallið hærra par sem jafnara yrði innan hópanna. Pað má álykta að ástæðuna fyrir hverfandi sambandi námsárangurs og menntunar foreldra eins og pað er kynnt í skýrslum Menntamálastofnunar (Almar M. Halldórsson o.fl., 2013; Menntamálastofnun, 2017) og víða annars staðar sé að rekja til pess að horft er á skýringarhlutfallið $\left(R^{2}\right)$, sem er ekki heppilegur mælikvarði á áhrifsstærð. Dannig sýna niðurstöður okkar að með pví að beina sjónum að ISCED-menntunarflokkum foreldra og tengslum peirra við árangur pátttakenda fáist greinarbetri mynd af tengslum pessara breyta.

Eigi leik- og grunnskólar að stuðla að jöfnum tækifærum allra, óháð félagslegri stöðu, parf að huga að ólíkum bakgrunni nemenda. Einkar mikilvægt er í pví sambandi að skólasamfélagið sé upplýst um pað að Ísland hafi ekki neina sérstöđu í pessum efnum. Dó félagsauður sé mikill í íslensku samfélagi pýðir bað ekki að félagsauður hafi almennt minni áhrif á námsgengi íslenskra nemenda en nemenda annars staðar, og æetla má að menntaðir foreldrar á Íslandi, rétt eins og menntaðir foreldrar í öðrum löndum, hafi áhrif á námsárangur barna sinna með margvíslegum hætti. Með auknum breytileika í íslensku samfélagi er mikilvægt að skólar hafi pað hlutverk að jafna tækifæri allra nemenda til menntunar. Pó staða skóla og heimila sé að meðaltali með pví besta sem gerist og betri en hjá mörgum OECD-pjóđum pá er hér á landi hópur barna sem býr við takmarkaðan félagsauð. Skólar starfa ekki í tómarúmi og pað að hlúa vel að börnum og gefa peim öllum tækifæri til að ná góðum árangri í námi verður alltaf samstarfsverkefni heimila, skóla og samfélagsins alls. Par má enginn skorast undan pví að prátt fyrir að PISA mæli einungis ákveðna hæfni benda rannsóknir til pess að niðurstöður úr PISA-prófum spái fyrir um ýmsa mikilvæga pætti, meðal annars hvort nemendur ljúka framhaldsskóla.

Dessi rannsókn byggist á gögnum úr PISA, bæði könnunum á náttúrufræðilæsi, lesskilningi og stærðfræðilæsi en einnig á svörum pátttakenda í spurningakönnun. Svör pátttakenda um menntun foreldra eru að öllum líkindum ekki fullkomlega áreiðanleg og verður að túlka niðurstöður í pví ljósi. Nauðsynlegt er að gera ráð fyrir peim möguleika að einhverjir pátttakendur endi einum flokki 
ofar eða neðar en peir ættu að vera og verður að gæta varúðar í túlkun á mismun meðalárangurs milli aðlægra menntunarflokka foreldra, par sem flokkarnir eru misstórir. Баð verður pó að teljast afar ósennilegt að mörg börn fari lengra frá réttum flokki en sem nemur einum. Ekki er hægt að fara ofar en í menntunarflokk 6, pannig að ef einhverjir eru ranglega flokkaðir par er líklegast að peir hefðu átt að vera í flokki 5. Menntunarflokkur 3 er alls staðar mun fjölmennari en menntunarflokkur 1 pví pað eru einfaldlega ekki margir foreldrar á Norðurlöndum sem eru með fyrra stig grunnmenntunar. Dví er sennilegt að í flokki 2 séu fleiri börn sem hefðu átt að enda ofar en neðar ef við gefum okkur pær forsendur að líkurnar á misflokkun séu svipaðar á milli menntunarflokka. Dví má segja að pað sé mun sennilegra að munur á námsárangri pátttakenda sem eiga foreldra með grunnskólamenntun og peirra sem eiga foreldra með háskólamenntun sé vanmetinn í pessum niðurstöðum en ofmetinn. Einnig má benda á að 30 stig á PISA-kvarðanum, sem OECD notar fyrir meðalframfarir nemenda á einu skólaári, er aðeins gróft viðmið sem túlka ætti með viðeigandi varúð. Vænta má töluverðs breytileika milli landa og einstaklinga í pessum efnum og hafa ætti í huga að viðmiðið setur mikinn punga á magntakanleika (e. quantifiability) pess sem mælt er (Michell, 1999).

Niðurstöður pessarar rannsóknar sýna að pótt aukin menntun foreldra sé alls staðar á Norðurlöndum tengd við mjög verulega bættan árangur nemenda í PISA, pá er sambandið ekki með sama hætti alls staðar á Norðurlöndum. Nauðsynlegt er að gera frekari rannsóknir til að kanna mögulegar skýringar á pessu. Í pví sambandi er hugsanlegt að samsetning nemendahóps, til að mynda mismunandi hlutfall innflytjenda, geti skipt máli ásamt breytileika á milli landa í inntaki menntunar á hverju skólastigi. Ekki er hægt að útiloka mismunandi kerfisbundnar mælivillur í bakgrunnsspurningakönnun PISA, svo sem að börn misskilji svarmöguleika um starfsmiðaða menntun á háskólastigi og petta geti verið mismunandi eftir löndum. Niðurstöðurnar sýna einnig hversu nauðsynlegt pað er að „,brjóta upp“ samsettar og ógagnsæjar mælingar OECD á pjóðfélagsstöðu nemenda og skoða í paula ályktanir sem byggjast á peim.

\section{The relation between parents' education level and students' performance in the PISA study}

Factors within school are not the sole determinants of academic performance. Research has shown that social circumstances, like parents and family, peer group, leisure-time activities as well as other factors in the larger social milieu of individuals affect educational attainment (Bong, 2008; Coleman et al., 1966; Morgan \& Sørensen, 1999; Sun, 1999). In this regard, research conducted in several different countries has consistently found that, of background factors, parents' level of education is one of the strongest predictors of student achievement (Davis-Kean, 2005; Israel, Beaulieu, \& Hartless, 2001; Magnuson, 2007; Sirin, 2005). Educated parents tend to have greater academic expectations and are more likely to motivate their children academically (Mullis, Rathge, \& Mullis, 2003). Furthermore, children of educated parents generally have more advantages and opportunities since their parents tend to be able to provide them with more educational resources and learning opportunities, as well as being more capable of helping them with academic course work (Gutman \& Eccles, 1999). In Iceland, some have argued, based on data from Iceland's participation in the Programme for International Student Assessment (PISA), that educational equality is one of the main strengths of the Icelandic education system. Reasons include that there is less difference between schools in Iceland than in any other OECD country and that the effect of social factors, such as parents' level of education, is almost nonexistent in the Icelandic school system (Almar M. Halldórsson, Ragnar F. Ólafsson, Óskar H. Níelsson, \& Júlíus K. Björnsson, 2010; Almar M. Halldórsson, Ragnar F. Ólafsson, \& Júlíus K. Björnsson, 2013; Menntamálastofnun, 2017). 
The PISA study is an international survey carried out triennially. Iceland has participated in the study since it was first conducted in the year 2000. The aim of the PISA study is to evaluate education systems worldwide by assessing 15 -year-old students, where many are near the end of their compulsory education. The PISA study assesses participants' knowledge in three core domains: literacy in reading, mathematics, and science. In 2015, the main focus was on science literacy. As well as testing these three domains, participants answer a questionnaire with questions relating to their background.

The current study is based on data from the 2015 PISA study, utilizing the sample from the five Nordic countries of Denmark, Finland, Norway, Iceland and Sweden. The aim of the study was to explore whether the relationship between student achievement and their parents' education level is different in Iceland than in the other Nordic countries. Furthermore, we expected that prior findings of very little association of parents' education level with student achievement could be due to the statistical methods used.

In reports on the main findings of PISA from the Icelandic Directorate of Education it is claimed that the association of parental education and student academic achievement is "practically 0" (Almar M. Halldórsson et al., 2010, 2013; Menntamálastofnun, 2017). This claim is based on the small value of the Pearson product moment coefficient of correlation $(r)$ and the coefficient of determination $\left(R^{2} / \eta^{2} \mathrm{RV}\right)$. This statistical approach is flawed for several reasons, most importantly that these coefficients describe the importance of the variance or heterogeneity of one variable for the variance of another and not the effect size in the unit of measurement. These coefficients can, therefore, be small as a result of little variability or homogeneity of the predictor. As achievement on PISA is measured on an equal-interval scale based on item-response theory that is neither test- nor population-specific, we simply compared mean achievement of students, conditional on parents' educational level. We also examined the proportion of students at each ability level (as defined by OECD) conditional on parents' educational level. Then, we examined the proportion of students at each ability level (as defined by OECD) conditional on parents' educational level.

Findings indicated that in all the Nordic countries there is considerable difference in the performance of participants whose parents have compulsory education compared with participants who have parents with higher education. Furthermore, our findings show that the Icelandic results are quite similar to the results from the other Nordic countries in this regard. If the OECD guideline for the average yearly progress of students is considered, the difference in achievement between Icelandic participants with parents who have compulsory education and those who have parents with higher education was two years for mathematics, over two years for literacy and close to two years for science.

Key words: PISA, parents' education, academic achievement, international comparisons 


\section{Um höfundana}

Berglind Gísladóttir (berglindg@hi.is) er lektor við Menntavísindasvið Háskóla Íslands. Hún lauk B.Ed.-grádu frá Kennaraháskóla Íslands 2002, M.Ed.-gráðu í stærðfræðimenntun frá Háskólanum í Reykjavík árið 2007 og doktorsprófi í stærðfræðimenntun frá Columbia-háskóla í New York árið 2013. Rannsóknaráhugi Berglindar beinist að námslegum og félagslegum páttum sem hafa áhrifá námsárangur nemenda. Einnig beinist áhuginn að fagpekkingu kennara og próun skólastarfs.

Hans Haraldsson (haha@hi.is) er verkefnisstjóri hjá Menntavísindastofnun Háskóla Íslands. Hann lauk B.S.-prófi í sálfræði frá Háskóla Íslands 2015 og stundar meistaranám í sálfræði og hagnýtri tölfræði, einnig við Háskóla Íslands.

Amalía Björnsdóttir (amaliabj@hi.is) er prófessor við Menntavísindasviði Háskóla Íslands. Hún lauk B.A.-prófi í sálfræði frá Háskóla Íslands árið 1991, M.Sc.-prófi frá háskólanum í Oklahoma 1994 og doktorsprófi frá sama skóla 1996. Hún hefur lagt stund á rannsóknir á sviði mælinga og prófagerðar, lestrar- og málproskamælinga, skólastjórnunar og áhrifa félagslegra pátta á skólastarf.

\section{About the authors}

Berglind Gísladóttir (berglindg@hi.is) is an assistant professor at the Faculty of Subject Teacher Education at the School of Education, University of Iceland. She completed a B.Ed. from the University of Iceland in 2002, an M.Ed. in Mathematics Education from Reykjavík University in 2007 and a Ph.D. in Mathematics Education from Columbia University in New York in 2013. Her main research interests are educational and social factors that affect student achievement.

Hans Haraldsson (haha@hi.is) is a project manager at the University of Iceland Educational Research Institute. He completed a B.S. degree in psychology from the University of Iceland in 2015 and is currently studying for master's degrees in psychology and applied statistics, also at the University of Iceland.

Amalía Björnsdóttir (amaliabj@hi.is) is a professor at the Faculty of Health Promotion, Sport and Leisure Studies at the School of Education, University of Iceland. She completed a B.A. degree in psychology from the University of Iceland in 1991, and a Ph.D. from the University of Oklahoma in 1996. Her major research interests are in the areas of measurement and testing (reading and language development), school management and impacts of social factors on education.

\section{Heimildir}

Almar M. Halldórsson, Ragnar F. Ólafsson og Júlíus K. Björnsson. (2013). Helstu niðurstöður PISA 2012. Lasi nemenda á starđfrað̇i og náttúrufreðði og lesskilningur. Sótt af https://mms.is/sites/mms. is/files/pisa_2012_island.pdf

Almar M. Halldórsson, Ragnar F. Ólafsson, Óskar H. Níelsson og Júlíus K. Björnsson. (2010). Íslenskir nemendur við lok grunnskólans. Helstu niðurstöður PISA 2009 rannsóknarinnar um lesskilning og lessi i stcerðfreði og náttúrufrexði. Sótt af https://mms.is/sites/mms.is/files/pisa_2009_island.pdf

Boardman, J. D., Powers, D. A., Padilla, Y. C. og Hummer, R. A. (2002). Low birth weight, social factors and developmental outcomes among children in the United States. Demography, 39(2), 353-368. doi:10.1353/dem.2002.0015

Bong, M. (2008). Effects of parent-child relationships and classroom goal structures on motivation, help-seeking avoidance, and cheating. The Journal of Experimental Education, 76(2), 191-217. 
Bourdieu, P. (1986). The forms of capital. Í J. Richardson (ritstjori), Handbook of theory and research for the sociology of education (bls. 241-258). Westport, CT: Greenwood Press.

Bourdieu, P. og Passeron, J.-C. (1990). Reproduction in education, society and culture. Beverly Hills: Sage.

Caro, D. H. og Biecek, P. (2017). Intsvy: An R package for analyzing international large-scale assessment data. Journal of Statistical Software, 81(7). doi:10.18637/jss.v081.i07

Castro, M., Expósito-Casas, E., López-Martín, E., Lizasoain, L., Navarro-Asencio, E. og Gaviria, J. L. (2015). Parental involvement on student academic achievement: A meta-analysis. Educational Research Review, 14, 33-46. doi:10.1016/j.edurev.2015.01.002

Coleman, J. S. (1988). Social capital in the creation of human capital. American Journal of Sociology, 94, 95-120.

Coleman, J. S., Campbell, E. Q., Hobson, C. F., McPartland, J., Mood, A. M. (1966). Equality of educational opportunity. Washington: U. S. Office of Education.

Coleman, J. S. og Hoffer, T. (1987). Public and private high schools: The impact of communities. New York: Basic Books.

Coleman, J. S., Hoffer, T. og Kilgore, S. (1982). High school achievement: Public, catholic and private schools compared. New York: Basic Books.

Davis-Kean, P. (2005). The influence of parent education and family income on child achievement: The indirect role of parent expectations and the home environment. Journal of Family Psychology, 19(2), 294-304. doi:10.1037/0893-3200.19.2.294

Faraway, J. J. (2002). Practical regression and ANOVA using R. Bath: University of Bath.

Fischbach, A., Keller, U. Preckel, F. og Brunner, M. (2013). PISA proficiency scores predict educational outcomes. Learning and Individual Differences, 24, 63-72. doi:10.1016/j.lindif.2012.10.012.

Gutman, L. M. og Eccles, J. S. (1999). Financial strain, parenting behaviors, and adolescents' achievement:Testing model equivalence between African American and European American single- and two-parent families. Child Development, 70(6), 1464-1476. doi:10.1111/1467-8624.00106

Halle, T., Kurtz-Costes, B. og Mahoney, J. (1997). Family influences on school achievement in low-income, African American children. Journal of Educational Psychology, 89(3), 527-537. doi:10.1037/0022-0663.89.3.527

Haveman, R. og Wolfe, B. (1995). The determinants of children's attainments: A review of methods and findings. Journal of Economic Literature, 33(4), 1829-1878.

Hill, H. C. (2017). The Coleman report, 50 years on: What do we know about the role of schools in academic inequality? The ANNALS of the American Academy of Political and Social Science, 674(1), 9-26. doi:10.1177/0002716217727510

Hoffer, T., Greeley, A. M. og Coleman, J. S. (1985). Achievement growth in public and catholic schools. Sociology of Education, 58(2), 74-97. doi:10.2307/2112249

Israel, G. D., Beaulieu, L. J. og Hartless, G. (2001). The influence of family and community social capital on educational achievement. Rural Sociology, 66(1), 44-68. doi:10.1111/j.1549-0831.2001. tb00054.x

Jensen, T. P. og Andersen, D. (2006). Participants in PISA 2000 - Four years later. Í J. Mejding og R. Astrid (ritstjórar), Northern lights on PISA 2003. A reflection from the Nordic countries (bls. 213-222). Kaupmannahöfn: Nordic Council of Ministers.

Magnuson, K. (2007). Maternal education and children's academic achievement during middle childhood. Developmental Psychology, 43(6), 1497-1512. doi:10.1037/0012-1649.43.6.1497

Martins, L. ogVeiga, P. (2010). Do inequalities in parents' education play an important role in PISA students' mathematics achievement test score disparities? Economics of Education Review, 29(6), 1016-1033. doi:10.1016/j.econedurev.2010.05.001 
Mazzeo, J. og von Davier, M. (2014). Linking scales in international large-scale assessments. Í L. Rutkowski, M. von Davier og D. Rutkowski (ritstjórar), Handbook of international large scale assessment: Background, technical issues, and methods of data analysis (bls. 229-258). New York: CRC Press.

Menntamálastofnun. (2017). Helstu niðurstöður PISA 2015. Sótt af https://mms.is/sites/mms.is/ files/helstu_nidurstodur_pisa_2015_prent_-_loka.pdf

Michell, J. (1999). Measurement in psychology: A critical history of a methodological concept (Vol. 53). Cambridge: Cambridge University Press.

Morgan, S. L. og Sørensen, A. B. (1999). Parental networks, social closure, and mathematics learning: A test of Coleman's social capital explanation of school effects. American Sociological Review, 64(5), 661-681. doi:10.2307/2657368

Mullis, R. L., Rathge, R. og Mullis, A. K. (2003). Predictors of academic performance during early adolescence: A contextual view. International Journal of Behavioral Development, 27(6), 541-548. doi:10.1080/01650250344000172

OECD. (1999). Classifying educational programmes manual for ISCED-97. Implementation in OECD countries. Sótt af http://www.oecd.org/education/skills-beyond-school/1962350.pdf

OECD. (2009). PISA data analysis manual: SPSS (2. útgáfa). Sótt af https://www.oecd-ilibrary.org/ education/pisa-data-analysis-manual-spss-second-edition_9789264056275-en

OECD. (2017). PISA 2015 technical report. Sótt af http://www.oecd.org/pisa/sitedocument/PISA-2015-technical-report-final.pdf

OECD. (2018). PISA 2015 Results in focus. Sótt af http://www.oecd.org/pisa/pisa-2015-resultsin-focus.pdf

Reimer, D., Jensen, S. S. og Kjeldsen, C. C. (2018). Social inequality in student performance in the Nordic countries: A comparison of methodological approaches. Í A. Wester (ritstjóri), Northern lights on TIMSS and PISA 2018 (bls. 31-59). Kaupmannahöfn: Nordic Council of Ministers.

Rutkowski, L. og Rutkowski, D. (2010). Getting it "better": The importance of improving background questionnaires in international large-scale assessment. Journal of Curriculum Studies, 42(3), 411-430. doi:10.1080/00220272.2010.487546

Rutkowski, D. og Rutkowski, L. (2013). Measuring socioeconomic background in PISA: One size might not fit all. Research in Comparative and International Education, 8(3), 259-278. doi:10.2304/ rcie.2013.8.3.259

Schleicher, A. (2007). Can competencies assessed by PISA be considered the fundamental school knowledge 15-year-olds should possess? Journal of Educational Change, 8(4), 349-357. doi:10.1007/ s10833-007-9042-x

Sirin, S. B. (2005). Socioeconomic status and academic achievement: A meta-analytic review of research. Review of Educational Research, 75(3), 417-453. doi:10.3102/00346543075003417

Steinberg, L. (1996). Ethnicity and adolescent achievement. American Educator, 28(2), 44-48.

Sun,Y. (1999). The contextual effects of community social capital on academic performance. Social Science Research, 28(4), 403-426. doi:10.1006/ssre.1999.0661

Thorlindsson, T., Bjarnason, T. og Sigfusdottir, I. D. (2007). Individual and community processes of social closure: A study of adolescent academic achievement and alcohol use. Acta Sociologica, 50(2), 161-178. Sótt af http://www.jstor.org/stable/20459990

Berglind Gísladóttir, Hans Haraldsson og Amalía Björnsdóttir (2019).

Samband menntunar foreldra við frammistöðu pátttakenda í PISA-könnuninni á Norðurlöndum

Netla - Veftímarit um uppeldi og menntun. Menntavísindasvið Háskóla Íslands.

Sótt af http://netla.hi.is/serrit/2019/altjodlegar_menntakannanir/03.pdf

DOI: https://doi.org/10.24270/serritnetla.2019.32 
Viðaukatafla 1. Fjöldi páttakenda, meðalárangur, staðalvillur meðaltala og staðalfrávik eftir löndum og horri menntunarflokki foreldris.

\begin{tabular}{|c|c|c|c|c|c|c|c|c|c|c|c|c|c|c|c|c|c|c|c|c|c|}
\hline \multirow{3}{*}{ Stæ. } & \multirow{3}{*}{$M f l}$. & \multicolumn{4}{|c|}{ Danmörk } & \multicolumn{4}{|c|}{ Finnland } & \multicolumn{4}{|c|}{ Ísland } & \multicolumn{4}{|c|}{ Noregur } & \multicolumn{4}{|c|}{ Svípjóð } \\
\hline & & $N$ & $M$ & Stv. & St.frv & $N$ & $M$ & Stv. & St.frv & $N$ & $M$ & Stv. & St.frv & $N$ & $M$ & Stv. & St.frv & $N$ & $M$ & Stv. & St.frv \\
\hline & & & & & & & & & & & & & & & & & & & & & \\
\hline & 2 & 862 & 475.3 & 4.1 & 74.8 & 71 & 441.1 & 16.9 & 85.6 & 191 & 442.6 & 7.7 & 92.5 & 99 & 444.7 & 9.2 & 82.2 & 188 & 424.1 & 8.3 & 78.2 \\
\hline & 3 & 550 & 492.6 & 4.5 & 76.0 & 529 & 479.6 & 4.8 & 76.9 & 136 & 450.3 & 9.8 & 87.4 & 150 & 479.5 & 8.4 & 85.8 & 294 & 475.9 & 6.4 & 76.1 \\
\hline & 4 & 485 & 489.8 & 6.7 & 82.1 & 479 & 485.8 & 4.8 & 77.3 & 554 & 479.2 & 4.6 & 82.7 & 1093 & 485.0 & 3.7 & 80.5 & 832 & 481.7 & 3.6 & 81.7 \\
\hline & 5 & 826 & 517.4 & 3.5 & 75.8 & 1173 & 502.0 & 3.1 & 76.0 & 302 & 468.5 & 6.2 & 86.3 & 1808 & 511.4 & 3.1 & 79.7 & 1022 & 493.2 & 3.6 & 82.6 \\
\hline & 6 & 4098 & 522.5 & 2.6 & 79.5 & 3510 & 525.8 & 2.5 & 81.4 & 2068 & 502.1 & 2.6 & 93.8 & 2052 & 511.7 & 3.0 & 88.2 & 2814 & 511.9 & 3.9 & 90.9 \\
\hline \multicolumn{22}{|l|}{ Les. } \\
\hline & 2 & 862 & 458.5 & 4.2 & 80.6 & 71 & 471.6 & 21.6 & 107.0 & 191 & 433.2 & 7.5 & 98.4 & 99 & 451.6 & 12.2 & 99.8 & 188 & 434.6 & 8.0 & 94.0 \\
\hline & 3 & 550 & 495.0 & 4.5 & 82.6 & 529 & 491.6 & 6.0 & 90.9 & 136 & 458.9 & 8.8 & 93.1 & 150 & 493.2 & 11.5 & 102.1 & 294 & 480.2 & 6.4 & 90.3 \\
\hline & 4 & 485 & 482.0 & 6.2 & 92.0 & 479 & 501.0 & 5.4 & 92.2 & 554 & 472.8 & 4.5 & 90.5 & 1093 & 495.8 & 3.7 & 94.0 & 832 & 488.8 & 4.3 & 92.9 \\
\hline & 5 & 826 & 504.0 & 4.3 & 81.3 & 1173 & 521.4 & 3.8 & 88.7 & 302 & 471.7 & 6.2 & 89.4 & 1808 & 530.2 & 3.1 & 91.0 & 1022 & 508.3 & 4.4 & 92.2 \\
\hline & 6 & 4098 & 510.9 & 3.1 & 86.3 & 3510 & 540.1 & 2.8 & 92.4 & 2068 & 494.0 & 2.5 & 101.2 & 2052 & 519.8 & 3.8 & 102.7 & 2814 & 517.5 & 4.2 & 101.4 \\
\hline \multicolumn{22}{|l|}{ Nát. } \\
\hline & 2 & 862 & 461.7 & 3.7 & 80.2 & 71 & 468.2 & 18.5 & 100.3 & 191 & 432.7 & 7.3 & 90.3 & 99 & 432.8 & 10.4 & 92.7 & 188 & 421.9 & 7.4 & 87.5 \\
\hline & 3 & 550 & 492.2 & 3.9 & 83.2 & 529 & 495.0 & 5.8 & 91.7 & 136 & 442.0 & 7.5 & 82.0 & 150 & 480.3 & 8.0 & 93.3 & 294 & 474.6 & 5.6 & 88.5 \\
\hline & 4 & 485 & 482.6 & 6.2 & 94.4 & 479 & 504.5 & 4.5 & 92.6 & 554 & 465.3 & 4.2 & 81.6 & 1093 & 479.3 & 3.2 & 89.6 & 832 & 483.1 & 3.8 & 91.7 \\
\hline & 5 & 826 & 508.2 & 3.7 & 84.6 & 1173 & 526.2 & 3.3 & 91.6 & 302 & 460.2 & 5.7 & 82.5 & 1808 & 513.1 & 2.7 & 89.7 & 1022 & 497.5 & 3.6 & 93.9 \\
\hline & 6 & 4098 & 513.0 & 3.0 & 90.1 & 3510 & 544.5 & 2.5 & 95.2 & 2068 & 485.6 & 2.2 & 93.2 & 2052 & 506.6 & 3.2 & 101.3 & 2814 & 511.0 & 4.5 & 104.4 \\
\hline
\end{tabular}

Skýringar:

Mfl. : Menntunarflokkur, N: Fjöldi, M: Meðaltal, Stv.: Staðalvilla meðaltals, St.frv.: Staðalfrávik. Stce.: Stærðfræðilæsi, Les. Lesskilningur, Nát.: Náttúrfræðilæsi. 
Viðaukatafla 2. Fjöldi páttakenda, meðalárangur, staðalvillur meðaltala og staðalfrávik eftir löndum og menntunarflokki móður.

\begin{tabular}{|c|c|c|c|c|c|c|c|c|c|c|c|c|c|c|c|c|c|c|c|c|c|}
\hline \multirow[b]{3}{*}{ Stæ. } & \multirow{3}{*}{ Mfl. } & \multicolumn{4}{|c|}{ Danmörk } & \multicolumn{4}{|c|}{ Finnland } & \multicolumn{4}{|c|}{ Ísland } & \multicolumn{4}{|c|}{ Noregur } & \multicolumn{4}{|c|}{ Svíbjóð } \\
\hline & & $N$ & & Stv. & St.frv & $N$ & $M$ & Stv. & St.frv & $N$ & $M$ & Stv. & St.frv & $N$ & $M$ & Stv. & St.frv & $N$ & $M$ & Stv. & St.frv \\
\hline & & & & & & & & & & & & & & & & & & & & & \\
\hline & 2 & 1224 & 479.8 & 3.7 & 76.5 & 186 & 467.0 & 9.2 & 83.4 & 455 & 459.3 & 4.9 & 88.7 & 240 & 463.1 & 6.6 & 83.4 & 331 & 443.5 & 6.8 & 82.9 \\
\hline & 3 & 693 & 500.3 & 4.4 & 78.2 & 651 & 485.9 & 3.8 & 76.2 & 131 & 454.1 & 9.5 & 93.4 & 233 & 483.8 & 6.9 & 81.5 & 442 & 485.0 & 5.4 & 79.0 \\
\hline & 4 & 477 & 499.1 & 5.7 & 80.3 & 613 & 489.8 & 3.9 & 81.1 & 623 & 484.8 & 4.4 & 85.4 & 1366 & 493.0 & 2.8 & 80.9 & 852 & 493.2 & 3.9 & 82.3 \\
\hline & 5 & 829 & 530.4 & 3.7 & 73.6 & 1320 & 509.0 & 3.1 & 77.9 & 208 & 466.9 & 7.2 & 91.4 & 1959 & 514.1 & 3.1 & 81.7 & 1140 & 499.9 & 3.4 & 84.4 \\
\hline & 6 & 3372 & 523.9 & 2.7 & 79.0 & 2929 & 528.2 & 2.6 & 80.8 & 1789 & 505.2 & 2.6 & 92.9 & 1329 & 513.1 & 3.4 & 89.2 & 2266 & 513.9 & 3.8 & 89.9 \\
\hline \multicolumn{22}{|l|}{ Les. } \\
\hline & 2 & 1224 & 466.0 & 4.0 & 84.7 & 186 & 488.1 & 11.7 & 101.8 & 455 & 458.3 & 4.8 & 95.2 & 240 & 471.5 & 8.9 & 99.2 & 331 & 452.8 & 7.2 & 98.0 \\
\hline & 3 & 693 & 496.4 & 4.6 & 83.8 & 651 & 498.1 & 4.8 & 88.1 & 131 & 464.8 & 9.8 & 97.7 & 233 & 495.9 & 9.1 & 96.3 & 442 & 493.3 & 5.5 & 88.3 \\
\hline & 4 & 477 & 487.0 & 5.3 & 88.7 & 613 & 502.8 & 4.7 & 94.3 & 623 & 478.7 & 4.1 & 89.3 & 1366 & 503.3 & 3.1 & 93.9 & 852 & 499.2 & 4.8 & 93.6 \\
\hline & 5 & 829 & 518.8 & 4.1 & 77.4 & 1320 & 527.8 & 3.5 & 90.3 & 208 & 464.8 & 7.3 & 95.2 & 1959 & 532.8 & 3.3 & 93.2 & 1140 & 512.1 & 4.3 & 92.7 \\
\hline & 6 & 3372 & 512.6 & 3.0 & 85.7 & 2929 & 543.0 & 3.0 & 91.3 & 1789 & 496.5 & 2.7 & 101.2 & 1329 & 519.4 & 4.2 & 104.6 & 2266 & 520.1 & 4.2 & 101.3 \\
\hline \multicolumn{22}{|l|}{ Nát. } \\
\hline & 2 & 1224 & 469.3 & 3.9 & 83.9 & 186 & 487.5 & 10.4 & 98.5 & 455 & 448.1 & 4.4 & 86.0 & 240 & 456.4 & 6.9 & 94.3 & 331 & 441.3 & 7.0 & 92.1 \\
\hline & 3 & 693 & 495.0 & 4.1 & 86.3 & 651 & 501.6 & 4.4 & 89.8 & 131 & 451.2 & 9.2 & 90.6 & 233 & 482.2 & 7.5 & 91.8 & 442 & 485.0 & 5.3 & 90.6 \\
\hline & 4 & 477 & 491.1 & 5.2 & 92.0 & 613 & 507.5 & 3.8 & 94.9 & 623 & 469.6 & 4.1 & 83.8 & 1366 & 488.3 & 2.8 & 90.8 & 852 & 494.5 & 4.3 & 92.1 \\
\hline & 5 & 829 & 522.6 & 3.9 & 82.1 & 1320 & 532.9 & 3.4 & 92.8 & 208 & 453.7 & 6.3 & 87.3 & 1959 & 515.5 & 2.9 & 91.4 & 1140 & 503.0 & 3.6 & 95.6 \\
\hline & 6 & 3372 & 514.7 & 3.0 & 89.3 & 2929 & 547.2 & 2.8 & 94.6 & 1789 & 488.8 & 2.3 & 92.5 & 1329 & 506.6 & 3.7 & 103.2 & 2266 & 513.6 & 4.4 & 104.1 \\
\hline
\end{tabular}

Skýringar:

Mfl. : Menntunarflokkur, N: Fjöldi, M: Meðaltal, Stv.: Staðalvilla meðaltals, St.frv.: Staðalfrávik. Stce.: Stærðfræðilæsi, Les. Lesskilningur, Nát.: Náttúrfræðilæsi. 
Viðaukatafla 3. Fjöldi páttakenda, meðalárangur, staðalvillur meðaltala og staðalfrávik eftir löndum og menntunarflokki föður.

\begin{tabular}{|c|c|c|c|c|c|c|c|c|c|c|c|c|c|c|c|c|c|c|c|c|c|}
\hline \multirow[b]{3}{*}{ Stæ. } & \multirow{3}{*}{$M f l}$. & \multicolumn{4}{|c|}{ Danmörk } & \multicolumn{4}{|c|}{ Finnland } & \multicolumn{4}{|c|}{ Ísland } & \multicolumn{4}{|c|}{ Noregur } & \multicolumn{4}{|c|}{ Svípjóð } \\
\hline & & $N$ & $M$ & Stv. & St.frv & $N$ & $M$ & Stv. & St.frv & $N$ & $M$ & Stv. & St.frv & $N$ & $M$ & Stv. & St.frv & $N$ & $M$ & Stv. & St.frv \\
\hline & & & & & & & & & & & & & & & & & & & & & \\
\hline & 2 & 1815 & 500.7 & 3.2 & 77.7 & 322 & 481.7 & 5.7 & 77.7 & 430 & 461.3 & 4.5 & 89.0 & 271 & 469.9 & 5.8 & 84.2 & 456 & 459.2 & 5.2 & 80.7 \\
\hline & 3 & 889 & 503.6 & 3.9 & 75.6 & 962 & 493.1 & 3.3 & 77.9 & 283 & 473.9 & 6.3 & 82.9 & 320 & 502.8 & 5.6 & 85.0 & 554 & 493.4 & 4.1 & 79.9 \\
\hline & 4 & 386 & 499.0 & 7.1 & 84.6 & 508 & 507.1 & 4.3 & 78.6 & 728 & 490.8 & 4.1 & 86.8 & 1580 & 494.5 & 3.5 & 81.9 & 962 & 492.5 & 3.5 & 83.4 \\
\hline & 5 & 806 & 512.6 & 3.5 & 75.8 & 1359 & 510.6 & 3.1 & 76.3 & 390 & 477.2 & 5.8 & 87.3 & 1382 & 518.3 & 3.0 & 78.4 & 1017 & 501.4 & 3.7 & 82.3 \\
\hline & 6 & 2637 & 528.4 & 3.1 & 80.6 & 2397 & 529.8 & 2.9 & 82.8 & 1305 & 508.8 & 3.1 & 96.6 & 1471 & 512.5 & 3.6 & 89.0 & 1921 & 516.5 & 4.6 & 93.0 \\
\hline \multicolumn{22}{|l|}{ Les. } \\
\hline & 2 & 1815 & 485.2 & 3.3 & 84.3 & 322 & 506.1 & 6.3 & 89.3 & 430 & 454.4 & 4.4 & 97.7 & 271 & 482.7 & 7.0 & 95.3 & 456 & 471.9 & 5.6 & 92.1 \\
\hline & 3 & 889 & 498.3 & 3.8 & 79.2 & 962 & 506.2 & 4.0 & 91.0 & 283 & 471.5 & 6.2 & 89.5 & 320 & 513.8 & 5.9 & 97.9 & 554 & 499.9 & 4.5 & 94.6 \\
\hline & 4 & 386 & 496.4 & 8.1 & 90.2 & 508 & 524.5 & 4.6 & 89.6 & 728 & 487.5 & 3.8 & 92.4 & 1580 & 508.1 & 3.2 & 95.1 & 962 & 502.5 & 3.9 & 93.2 \\
\hline & 5 & 806 & 499.6 & 4.1 & 82.8 & 1359 & 527.2 & 4.0 & 88.9 & 390 & 480.3 & 5.0 & 90.4 & 1382 & 535.6 & 3.5 & 89.2 & 1017 & 514.1 & 4.1 & 91.2 \\
\hline & 6 & 2637 & 518.5 & 3.7 & 87.1 & 2397 & 544.2 & 3.2 & 93.8 & 1305 & 498.3 & 3.4 & 104.8 & 1471 & 520.1 & 4.4 & 103.8 & 1921 & 521.5 & 4.8 & 102.4 \\
\hline \multicolumn{22}{|l|}{ Nát. } \\
\hline & 2 & 1815 & 490.7 & 2.9 & 86.6 & 322 & 507.2 & 6.2 & 90.6 & 430 & 450.0 & 4.0 & 88.8 & 271 & 467.8 & 7.9 & 92.8 & 456 & 458.8 & 5.3 & 90.3 \\
\hline & 3 & 889 & 496.4 & 3.5 & 81.6 & 962 & 511.1 & 3.8 & 91.5 & 283 & 462.5 & 5.3 & 80.3 & 320 & 498.5 & 5.5 & 95.4 & 554 & 494.0 & 4.1 & 92.1 \\
\hline & 4 & 386 & 490.9 & 7.6 & 94.6 & 508 & 525.5 & 4.6 & 93.2 & 728 & 479.9 & 3.6 & 85.5 & 1580 & 490.5 & 3.1 & 92.6 & 962 & 494.9 & 3.6 & 94.1 \\
\hline & 5 & 806 & 503.2 & 3.8 & 85.5 & 1359 & 532.3 & 3.5 & 91.6 & 390 & 469.0 & 4.9 & 83.4 & 1382 & 520.0 & 2.8 & 88.3 & 1017 & 504.0 & 4.0 & 93.8 \\
\hline & 6 & 2637 & 520.0 & 3.6 & 91.5 & 2397 & 549.0 & 3.0 & 96.7 & 1305 & 488.6 & 2.8 & 96.4 & 1471 & 507.8 & 3.8 & 101.9 & 1921 & 515.9 & 5.3 & 106.5 \\
\hline
\end{tabular}

Skýringar:

Mfl. : Menntunarflokkur, N: Fjöldi, M: Meðaltal, Stv.: Staðalvilla meðaltals, St.frv.: Staðalfrávik. Stce.: Stærðfræðilæsi, Les.

Lesskilningur, Nát.: Náttúrfræðilæsi. 